\title{
Proterozoic Geology of the Brady Butte area, Yavapai County, Arizona
}

U.S. G EOLOG I CAL SURVEY BULLETIN 1548
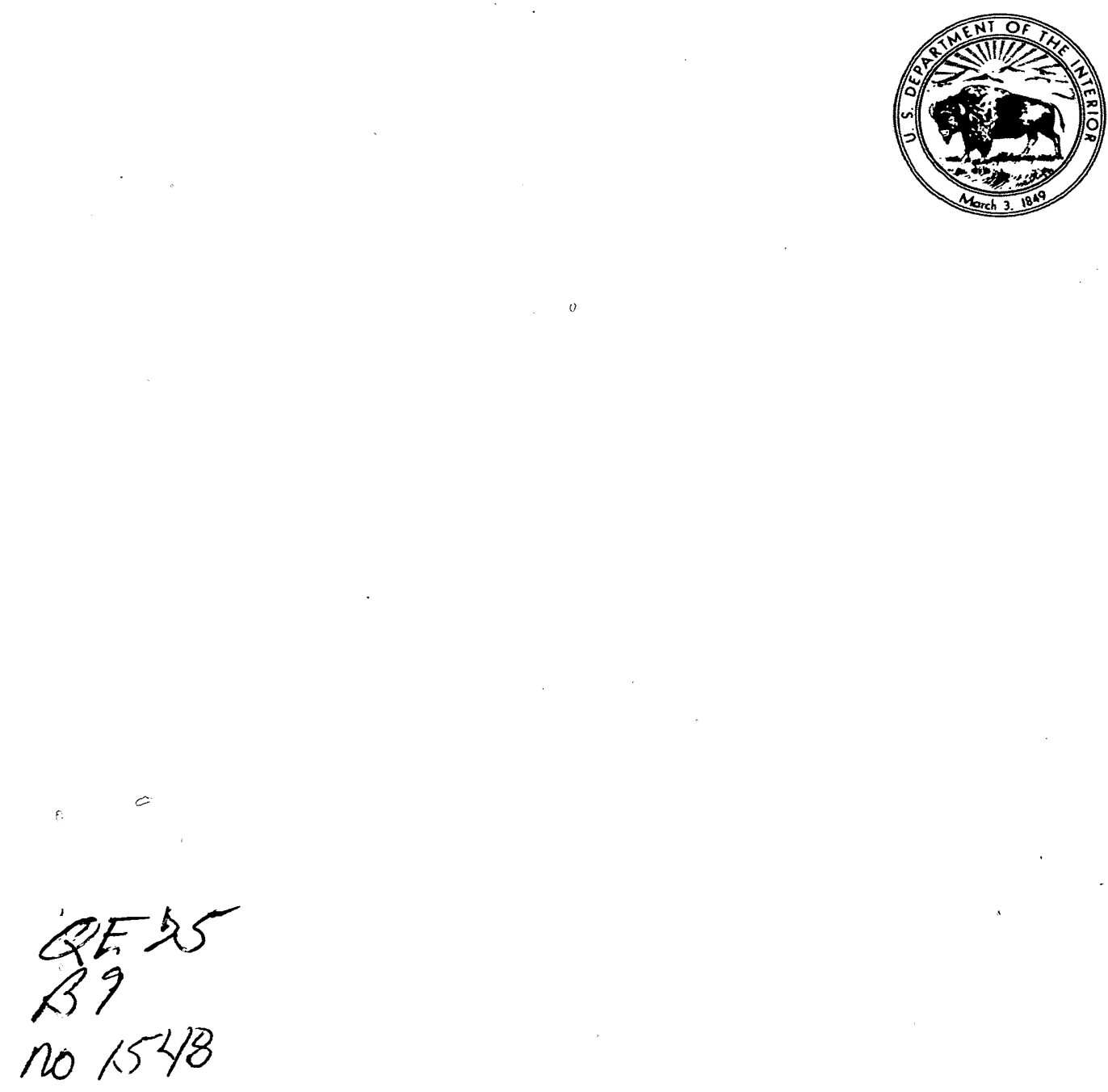


\section{Proterozoic Geology of the Brady Butte area, Yavapai County, Arizona}

By PHILIP M. BLACET

U.S. GEOLOGICAL SURVEY B ULLETIN 1548

A study of the stratigraphy and structure of the Proterozoic stratified and associated intrusive rocks 


\title{
DEPARTMENT OF THE INTERIOR
}

DONALD PAUL HODEL, Secretary

\author{
U.S. GEOLOGICAL SURVEY
}

Dallas L. Peck, Director

\section{Library of Congress Cataloging-in-Publication Data}

Blacet, Philip Merrill, 1937-

Proterozoic geology of the Brady Butte area, Yavapai County, Arizona

(U.S. Geological Survey Bulletin 1548)

Bibliography

Supt. of Docs. No.: I 19.3:1548

1. Geology, Stratigraphic-Precambrian. 2. Geology, Arizona-Brady Butte Region. I. Title. 11. Series: United States. Geological Survey. Bulletin 1548.

QE75.B9 no. 1548

[QE653]
$557.3 \mathrm{~s}$ [551.7'15'0979157]

For sale by the Distribution Branch, U.S. Geological Survey, 604 South Pickett Street, Alexandria, VA 22304 


\section{CONTENTS}

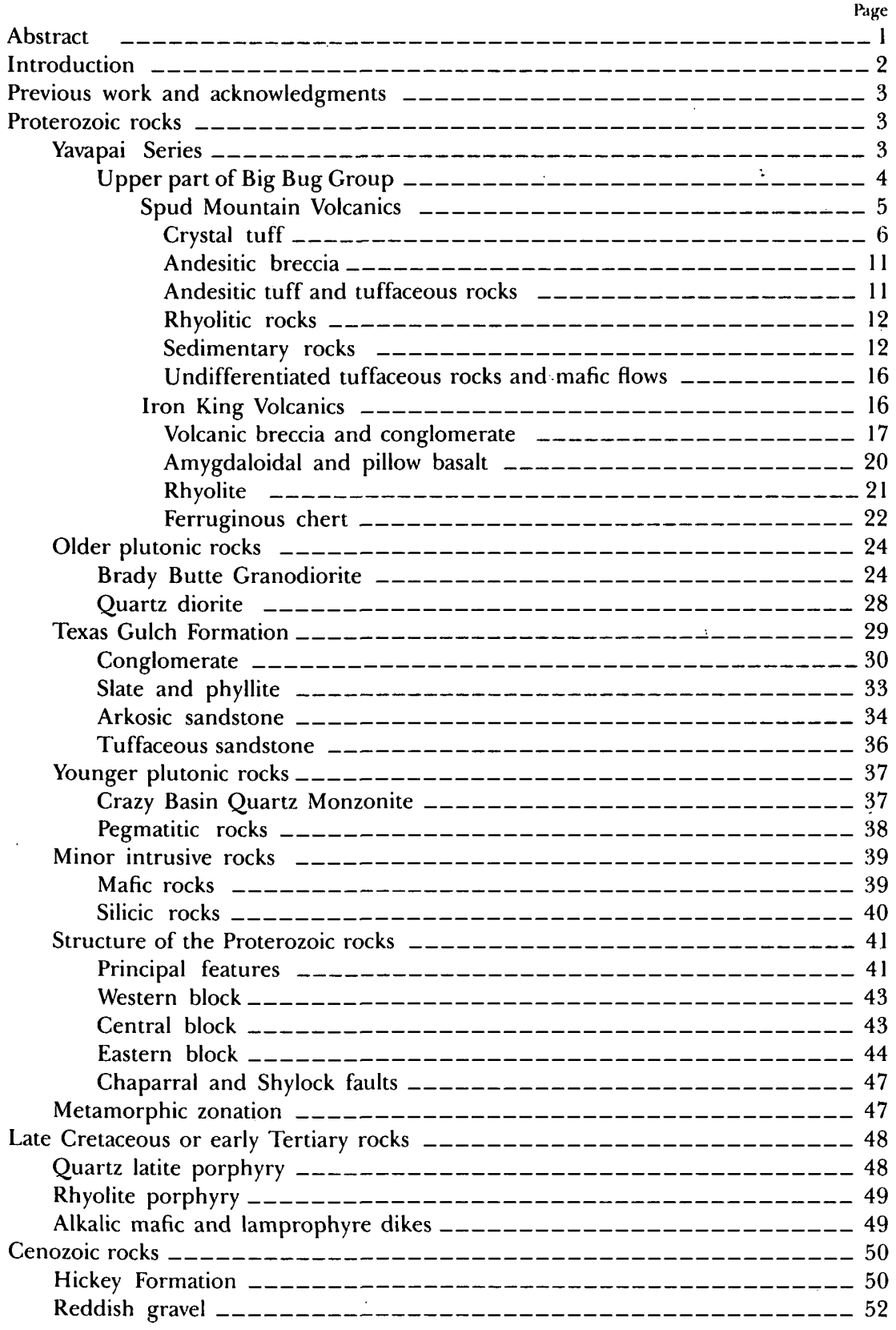


Ore deposits - - -

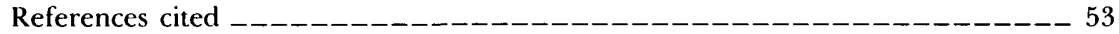

\section{ILLUSTRATIONS}

Plate 1. Geologic map of the Brady Butte area, Yavapai County, Arizona

2. Generalized geology and structure of the Brady Butte and surrounding area, Arizona

In pocket In pocket Page

Figure 1. Index map of Arizona showing location of Brady Butte area $\mathrm{SE}^{1 / 4}$ Mount Union quadrangle

2. Photographs of crystal tuff and moderately foliated crystal tuff in the Spud Mountain Volcanics

3. Photograph showing compositional layering reflecting stratification in sedimentary rocks

4. Photograph showing small-scale slip folds in relict bedding $\left(S_{1}\right)$ and foliation $\left(\mathrm{S}_{2}\right)$ in sedimentary rocks of the Spud Mountain Volcanics

5. Photomicrograph showing coarse-grained muscovite schist at contact of the Crazy Basin Quartz Monzonite

6. Photographs showing volcanic breccia and conglomerate in the Iron King Volcanics

7. Photograph showing relict pillows in amphibolite-facies metabasalt of the Iron King Volcanics

8. Ternary diagram showing modal composition of six samples and average mode of the Brady Butte Granodiorite by plutonic rock classification used in this report

9. Photograph of boulder conglomerate at the base of Texas

Gulch Formation

10. Photograph showing crossbedded arkosic sandstone in the

Texas Gulch Formation

11. Generalized structure map of contact aureole around the Crazy Basin Quartz Monzonite

TABLES
46

TABLE 1. Chemical analyses and C.I.P.W. norms in the Spud Mountain

Volcanics and Iron King Volcanics

2. Chemical analyses and C.I.P.W. norms of Brady Butte Granodiorite

and Crazy Basin Quartz Monzonite

3. Chemical analyses and C.I.P.W. norms of Late Cretaceous or early

Tertiary rhyolitic and mafic alkaline dikes 


\title{
PROTEROZOIC GEOLOGY OF THE BRADY BUTTE AREA, YAVAPAI COUNTY, ARIZONA
}

\author{
By Philip M. Blacet
}

\begin{abstract}
The Brady Butte area lies in the Battle Flat $7 \frac{1}{2} 2$-minute quadrangle, which is the southeast quarter of the Mount Union 15-minute quadrangle. The oldest Proterozoic rocks exposed in the area belong to the Big Bug Group, which consists of three formations: the Green Gulch, Spud Mountain, and Iron King Volcanics. However, only the latter two are exposed in the Brady Butte area.

The Spud Mountain Volcanics exposed in the west margin of the area consist of a thick sequence of crystal tuff that intertongues with andesitic breccia. Younger andesitic tuffaceous rocks are exposed on the west limb of a north-plunging overturned anticline. In the southeast corner of the quadrangle, an upper sedimentary unit in the Spud Mountain Volcanics is intruded by the Crazy Basin Quartz Monzonite, producing appreciable recrystallization and deformation. Three well-developed contact metamorphic zones indicate that temperatures increased rapidly toward the pluton during its emplacement.

The Iron King Volcanics, which overlies the Spud Mountain Volcanics and is the youngest formation in the Big Bug Group, consists dominantly of basaltic flows that contain pillow and amygdaloidal structures. Interbeds of chert are common in the northern exposures, and volcanic breccias form a large sequence at the base of the section.

Much of the central part of the area is dominated by the Brady Butte Granodiorite, $1,770 \pm 10$ m.y. in age, flanked by the younger Texas Gulch Formation, largely along fault contacts except at the northern exposures where the Texas Gulch Formation is in depositional contact with the underlying pluton. The only exposure of the intrusive contact of the Brady Butte Granodiorite is in the southwest corner of the area where it intrudes the Spud Mountain Volcanics.

Steeply dipping north- to northeast-striking faults showing large vertical separation divide the Proterozoic rocks into three structural blocks: a western block of the northwest-dipping Spud Mountain Volcanics, a central anticlinal block of the Brady Butte Granodiorite and unconformably overlying Texas Gulch Formation, and an eastern northwest-dipping conformable section of the Spud Mountain and Iron King Volcanics.

Mining activity started about 1875; two mines, the Peck and the Swastika, are reported to have produced about $\$ 2 \frac{1}{2}$ million in silver from oxidized quartz veins, presumably of Mesozoic or early Tertiary age. Overlapping lenses of pyrite and chalcopyrite in the Iron King Volcanics were mined from the DeSoto mine in the early part of the 20th century; recorded production, mostly copper, was valued at $\$ 3,250,000$.
\end{abstract}




\section{INTRODUCTION}

The SE $1 / 4$ of the Mount Union 15-minute quadrangle (Battle Flat $71 / 2$ minute quadrangle), central Arizona, hereinafter called the Brady Butte area, is a part of the Bradshaw Mountains and is underlain largely by Proterozoic metasedimentary and metavolcanic rocks of the Big Bug Group and a pluton, the Brady Butte Granodiorite. This area is a part of the Bradshaw Mountains that extends southward from Prescott, Ariz. Earlier detailed studies of the Precambrian rocks north and northeast of the Bradshaw Mountains were made in the Prescott quadrangle (Krieger, 1965) and in the Mingus Mountain quadrangle (Anderson and Creasey, 1958). Later detailed mapping in the $\mathrm{NE}^{1 / 4}$ Mount Union and the NW $1 / 4$ Mayer quadrangles (Anderson and Blacet, 1972a) extended the map coverage to the south. The work in the SE $1 / 4$ of the Mount Union quadrangle completes the detailed mapping of the eastern half of the Mount Union quadrangle (fig. 1).

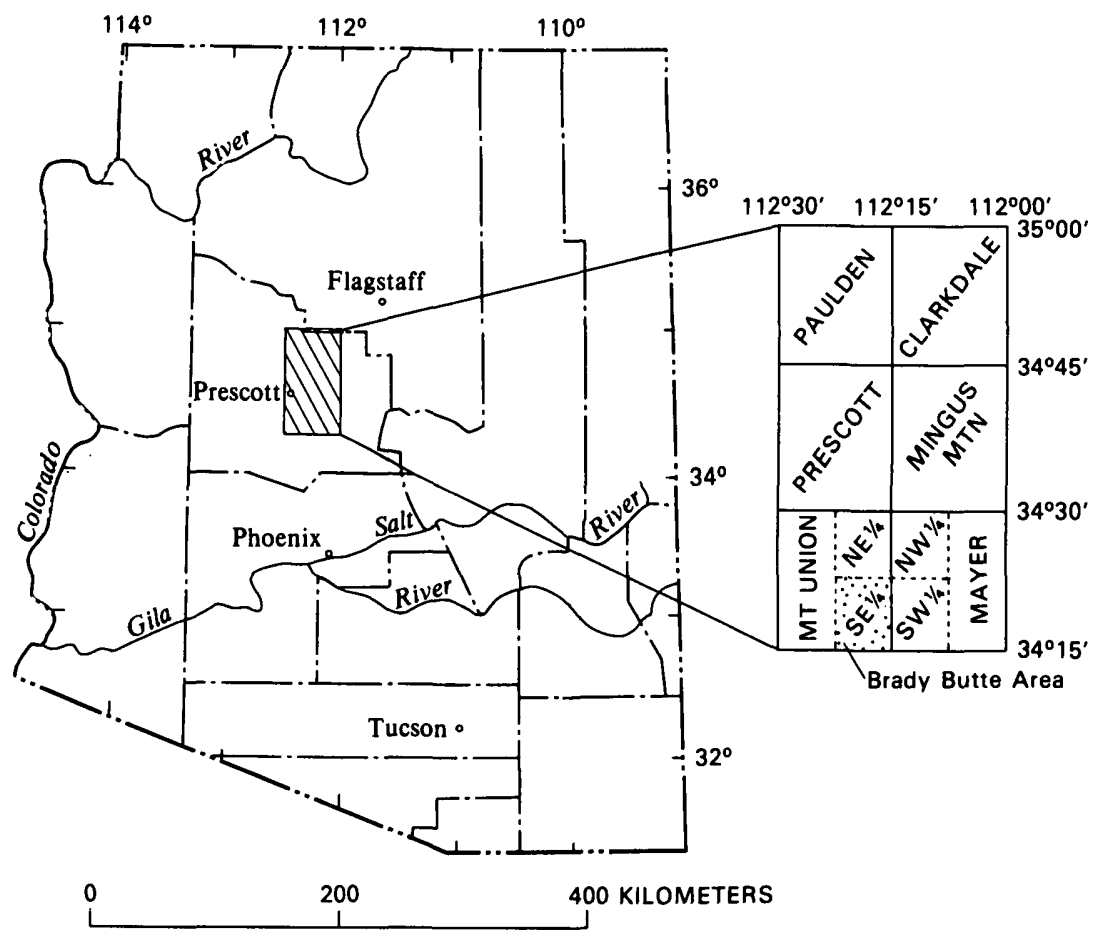

FIguRE 1.-Index map of Arizona showing location of the Brady Butte area, SE1/4 Mount Union quadrangle. 


\section{PREVIOUS WORK AND ACKNOWLEDGMENTS}

The pioneer work of Jaggar and Palache (1905) is the first description of the Precambrian rocks in the Bradshaw Mountains; the classic report of the mines and prospects by Lindgren followed in 1926.

Geologic mapping of the Brady Butte area was begun in June 1961 and completed in March 1964, after approximately 8 months' field studies. C. A. Anderson provided counsel and participated in numerous discussions in the field and in the office. R. R. Compton, D. M. Morton, and F. K. Miller provided assistance in the field studies.

L. T. Silver, California Institute of Technology, and T. W. Stern provided isotopic dating of the Precambrian volcanic and plutonic rocks in the Brady Butte area that helped resolve some of the stratigraphic and structural problems.

Geologic maps have been published on these adjacent areas: Paulden and Prescott quadrangles (Krieger, 1965), Mingus Mountain quadrangle (Anderson and Creasey, 1958, 1967), Clarkdale quadrangle (Lehner, 1958), NE $1 / 4$ Mount Union and NW1/4 Mayer quadrangles (Anderson, 1972), Mount Union quadrangle (Anderson and Blacet, 1972b), and Mayer quadrangle (Anderson and Blacet, 1972c).

\section{PROTEROZOIC ROCKS}

\section{YAVAPAI SERIES}

The Precambrian stratified rocks in the Prescott and Jerome areas were assigned to the Yavapai Series by Anderson and Creasey (1958). Two groups are distinguished in the Mingus Mountain quadrangle, the Ash Creek and the Alder, separated by the Shylock fault with no evidence to indicate their age relations. Later isotope dating proved that the Ash Creek Group is older than the Alder and that the term "Alder Group" should be replaced in the Jerome, Prescott, and Mayer areas by the new name Big Bug Group (Anderson and others, 1971). In the Brady Butte area, the Big Bug Group is the only part of the Yavapai Series exposed. Isotopic dates make it possible to use the name Yavapai Series as a time-stratigraphic term in a provincial sense, defined as rocks of the time interval 1,770 \pm 10 m.y. to 1,820+ m.y. (Anderson and others, 1971).

The stratified rocks making up the Yavapai Series are dominantly of volcanic origin, and most of the bedded clastic rocks consist of volcanic 
detritus. As relict textures and structures in general are sufficiently well preserved that the character of the rocks prior to metamorphism can be determined, the prefix "meta" is not used in the stratigraphic nomenclature. Most of the rocks in the Yavapai Series are in the greenschist facies of metamorphism, but in the southeastern part of the Brady Butte and adjacent Cordes areas, quartz-mica schists locally contain garnet and staurolite near the Crazy Basin Quartz Monzonite, where relict textures are largely destroyed. The terms Ssurfaces, relict bedding, and foliation are used in this report as here defined:

$S$-surfaces.-S-surface is used to denote penetrative planar or curviplanar structures in deformed rocks. If more than one such structure is present, they are designated $S_{1}, S_{2}, S_{3}$, and so on in order of decreasing age. Rocks described in this report commonly exhibit three $\mathrm{S}$ surfaces: relict bedding, $S_{1}$; axial plane foliation, $S_{2}$; and strain-slip cleavage, $S_{3}$. S-surfaces that are presumed to be synchronous and dynamically equivalent are denoted by the same $S$ symbol. For example, strain or strain-slip cleavage (defined by microflexure of $\mathrm{S}_{2}$ into discrete crosscutting planes) in schistose rocks and related fracture cleavage (defined by a closely spaced set of discrete fractures unrelated to mineral orientation) in interbedded quartzitic rocks are both designated $\mathrm{S}_{3}$.

Relict bedding.-Relict bedding $\left(\mathrm{S}_{1}\right)$ is used conservatively for metamorphosed stratification in which sedimentary textures or structures can be recognized, or for layering that has an external form and composition distinctive of a sedimentary rock (see fig. 11). Compositional or textural layering of uncertain origin (see fig. 3), in part resulting from extreme disruption and transposition of $S_{1}$, is referred to as foliation $\left(\mathrm{S}_{2}\right)$ because nearly everywhere it parallels a conspicuous preferred orientation of micaceous minerals and the axial planes of folds.

Foliation.- "Foliation" is used to include all S-surfaces of metamorphic origin. It is a general term that encompasses schistosity and cleavage as well as lithologic layering caused by metamorphic differentiation or extreme deformation. Commonly, the foliation described in this report is defined by the parallel arrangement of platy or elongate mineral grains. This preferred orientation is generally approximately parallel to the axial planes of the mesoscopic and macroscopic folds and constitutes an axial-plane foliation. Within the appressed and attenuated limbs of the major isoclinal folds, the foliation is commonly parallel to relict bedding and may be called bedding-plane foliation.

\section{UPPER PART OF BIG BUG GROUP}

The Big Bug Group is exposed along the west margin of the Mingus Mountain quadrangle (Anderson and Creasey, 1958), in the southern 
part of the Prescott quadrangle (Krieger, 1965), and in the Brady Butte area. In these publications the term "Alder Group" was used to include the Green Gulch Volcanics, Spud Mountain Volcanics, Iron King Volcanics, Texas Gulch Formation, Indian Hills Volcanics, and Chaparral Volcanics. Later studies (Anderson and Creasey, 1967; Anderson and others, 1971) demonstrated that the Indian Hills Volcanics is a synonym for the Green Gulch Volcanics and that the Chaparral Volcanics, bounded by faults, constitutes the upper part of the Spud Mountain Volcanics. Consequently the names Indian Hills and Chaparral Volcanics were abandoned. The Texas Gulch Formation was removed from the Yavapai Series because it is separated from the Big Bug Group by a period of plutonism, represented by the Brady Butte Granodiorite, and subsequent erosion.

The Big Bug Group is now divided into three formations, from oldest to youngest, the Green Gulch, Spud Mountain, and Iron King Volcanics. The Green Gulch Volcanics contains pillow and amygdaloidal mafic flows. The Spud Mountain Volcanics consists of an intertonguing complex of andesitic and rhyolitic pyroclastic rocks and amygdaloidal mafic flows. The Iron King consists largely of basaltic flows. The actual stratigraphic thickness of the Big Bug Group cannot be measured with certainty because of the probability that unrecognized small folds on the flanks of the major folds duplicate the stratigraphic section. Some of the volcanic units in the group are highly lenticular. A reasonable estimate of the thickness is $6,100 \mathrm{~m}$.

Only the upper two formations of the Big Bug Group, the Spud Mountain and Iron King Volcanics, are exposed in the Brady Butte area. The older Green Gulch Volcanics is largely limited to the northwestern and southwestern parts of the Mount Union and Prescott quadrangles.

\section{SPUD MOUNTAIN VOLCANICS}

The Spud Mountain Volcanics was first described by Anderson and Creasey $(1958$, p. 21) from exposures in the northeast corner of the Mount Union quadrangle. At the type locality, the lower part of the volcanic sequence consists largely of andesitic breccia overlain by bedded andesitic and rhyolitic tuffaceous rocks. Intertonguing andesitic flows appear throughout the section. Southward toward the Brady Butte area, the exposures of andesitic breccia are greatly reduced in volume, and massive poorly bedded crystal tuff intertongues with andesitic breccia and bedded andesitic tuff.

The Spud Mountain Volcanics crops out in an area of about $26 \mathrm{~km}^{2}$ in the western part of the Brady Butte area (pl. 1); most of this block is north of Battle Flat, where fine-grained andesitic tuff, crystal tuff, and andesitic breccia are in fault contact with the western belt of Texas Gulch Formation. Southwest of Battle Flat, fine-grained andesitic tuff 
has been intruded by a porphyritic facies of the Brady Butte Granodiorite.

Immediately west of the Brady Butte area, the Spud Mountain Volcanics is extensively intruded by numerous small sills, dikes, and pluglike bodies of aplite, diorite, and gabbro, whereas about $1.6 \mathrm{~km}$ west of the area, amphibolitic Spud Mountain Volcanics is completely disrupted by plutonic rocks that Jaggar and Palache (1905) mapped as mixed plutonic and metamorphic terrane, the Crooks Complex. ${ }^{1}$

Large-scale faulting related to the uplift of the central block of Brady Butte Granodiorite and Texas Gulch Formation has cut off the basal part of the Spud Mountain Volcanics, making it difficult to determine the total thickness of the formation in this western block. Bedding generally dips northwestward at an angle close to $70^{\circ}$; if stratigraphic duplication has not occurred, the volcanic succession may be $3,600 \mathrm{~m}$ thick, with neither base nor top exposed. There is some evidence to suggest that the structure of the western block is dominated by an isoclinal overturned anticline (pl. 2), making the thickness of these volcanic rocks probably about 1,500 to $1,800 \mathrm{~m}$.

\section{Crystal Tuff}

Crystal tuff of dacitic composition (pl. 1) constitutes the greatest bulk of the Spud Mountain Volcanics in the western part of the Brady Butte area. North of $1,215,000 \mathrm{~N}^{2}$, the crystal tuff is intimately mixed with andesitic breccia and bedded fine-grained andesitic tuff, which become the dominant lithologies of the Spud Mountain Volcanics northward into the $\mathrm{NE}^{1 / 4}$ of Mount Union quadrangle (Anderson and Blacet, 1972a). The lenticular outcrop pattern of these three lithologic units in part reflects isoclinal folding, but original stratigraphic intertonguing was probably the dominant factor in the determination of the outcrop pattern.

About $1.5 \mathrm{~km}$ north of the Brady Butte area, the crystal tuff grades rapidly into, or plunges beneath, fine-grained andesitic bedded tuff; farther north, this bedded tuff grades into andesitic breccia. These lithologic variations occur along a line parallel to the strike of the bedding and $\mathrm{S}_{2}$ foliation, which coincides with the axis of an overturned anticline (Anderson and Blacet, 1972a, pl. 1). The crystal tuff, which locally contains andesitic clasts, is markedly similar in lithology to the matrix of the breccia. These two units form intertonguing equivalent facies, exposed in the core of a saddle-shaped anticlinal structure. This interpretation suggests that the small area of fine-

1The Crooks Complex is obsolete as a formation owing to subsequent subdivision (Anderson and Blacet, 1972).

210,000-ft grid based on Arizona coordinate system, central zone. 
grained tuff between the breccia and crystal tuff occupies the depressed central part of the hypothetical saddle (pl. 2).

The term "crystal tuff" was applied to poorly or massive bedded rocks characterized by abundant relict plagioclase crystals and crystal fragments set in a fine-grained recrystallized matrix (fig. $2 A$ ). Bluishgray slightly opalescent quartz clasts are common in the crystal tuff, but generally are less abundant than plagioclase crystals (fig. $2 B$ ). Fresh crystal tuff is medium olive gray to dark greenish gray; close inspection reveals a mottling imparted by scattered quartz and plagioclase crystals. Weathering lightens the rock to light olive gray, tan, or where weathered to a depth of several feet, reddish brown. Although outcrops of the crystal tuff occur widely, are numerous, and commonly of large size, rocks of this lithology are probably the most poorly exposed in the Brady Butte area.

Foliation is penetrative and generally evident in outcrops. South of coordinate $1,210,000 \mathrm{~N}$., in the general vicinity of Battle Flat, bluegreen amphibole has crystallized at the expense of chlorite, and here the crystal tuff weathers to blocky outcrops that appear less foliated than those to the north.

The intensity of foliation is variable within the crystal tuff, but its spatial orientation is remarkably consistent, the strike trending N. $20^{\circ}$ E. to N. $40^{\circ} \mathrm{E}$., and the dip consistently northwest at $60^{\circ}-85^{\circ}$. This foliation can be designated $\mathrm{S}_{2}$ with some confidence, as it is essentially parallel to the relict bedding, the general trend of included or closely associated lenses of andesitic breccia, the axial trend of digitations along the crystal tuff-andesitic tuff contact (pl. 1), the axial planes of small-scale folds, and the axial planes of large-scale isoclinal folds recognized within adjacent parts of the Big Bug Group (pl. 2).

The texture of typical Spud Mountain crystal tuff is shown in figure 2. Stubby subhedral crystals and crystal clasts of albite (oligoclase from Battle Flat southward) are clouded with sericite and clinozoisite or epidote, commonly with included blebs of quartz. Partial replacement of plagioclase crystals by coarse semiradiating or subhedral epidote clots with interstitial quartz is common. Composite crystals or small clusters of plagioclase crystals are not uncommon, but generally the plagioclase occurs as moderately rounded euhedral to subhedral crystals ranging from 0.3 to $5 \mathrm{~mm}$ in maximum diameter. Euhedral plagioclase crystals are common in much of the crystal tuff, and no clearly embayed plagioclase has been observed. Chemical analyses of the three facies of the Spud Mountain crystal tuff are given on table 1, numbers 1,2 , and 3 .

Relict quartz occurs as rounded and deeply embayed bipyramidal crystals 1 to $5 \mathrm{~mm}$ in diameter. The rounding and embayment of the quartz crystals probably resulted from the partial resorption of beta- 

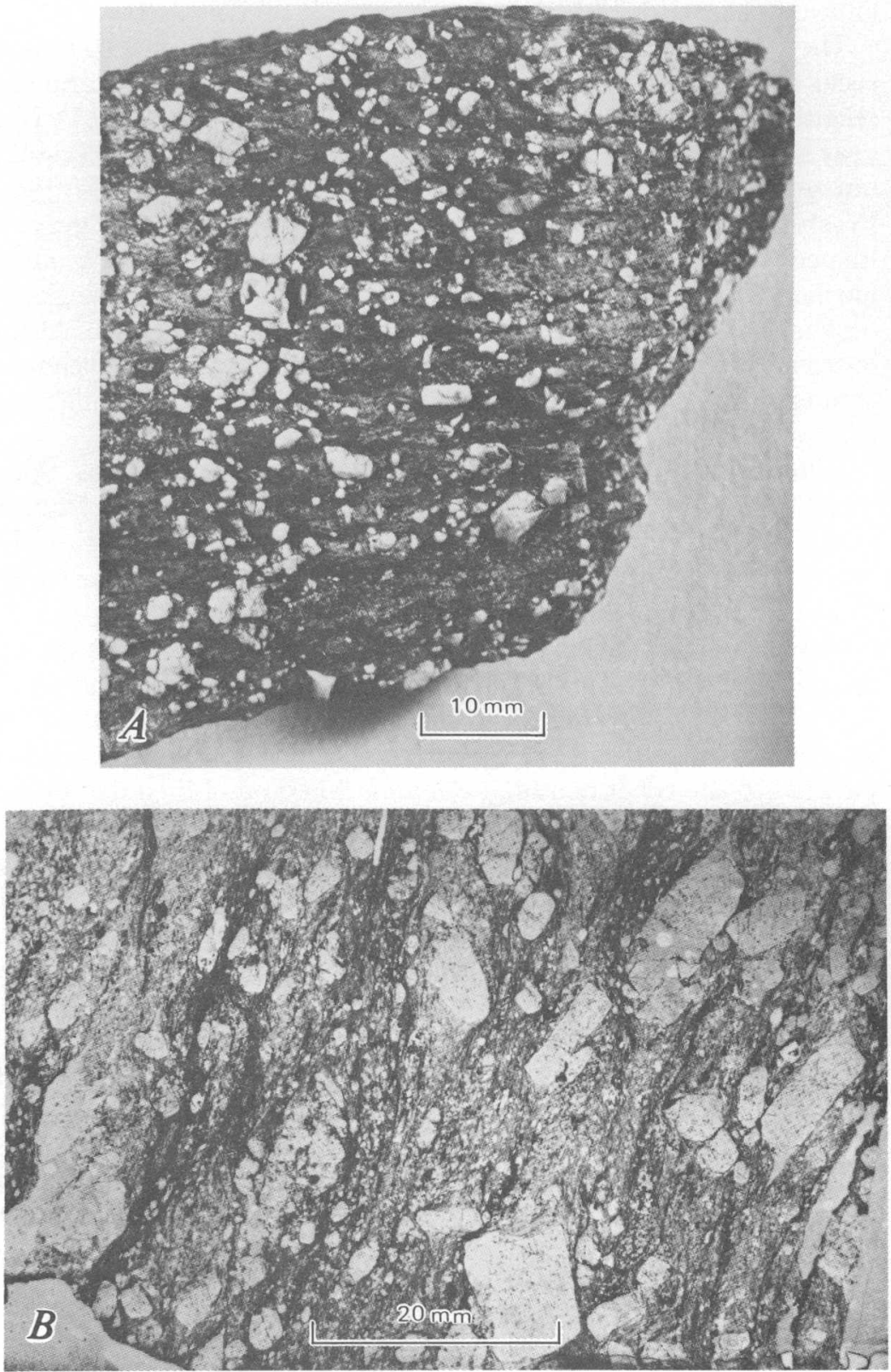

Figure 2.-Crystal tuff in the Spud Mountain Volcanics. A, Euhedral and wellrounded plagioclase crystals are intermixed in poorly sorted volcaniclastic rock. $B$, Moderately foliated crystal tuff; blue-gray quartz euhedrons and rounded grains mixed with plagioclase crystals. 
TABLE 1.--Chemical analyses and C.I.P.W. norms of rocks in the Spud Mountain Volcanics and Iron King Volcanics

[Chemical analyses by rapid rock method; analysts: Paul L. D. Elmore, Lowell Artis, Samuel Botts, Gillison Chloe, John Glenn, and Hezekiah Smith]

\begin{tabular}{|c|c|c|c|c|c|c|c|}
\hline & 1 & 2 & 3 & 4 & 5 & 6 & 7 \\
\hline \multicolumn{8}{|c|}{ Chemical analyses (in weight percent) } \\
\hline $\mathrm{SiO}_{2}----\infty-\infty$ & 64.1 & 64.4 & 62.7 & 62.9 & 47.6 & 45.9 & 53.8 \\
\hline $\mathrm{Al}_{2} \mathrm{O}_{3}---\cdots$ & 14.5 & 15.1 & $15 \cdot 2$ & 17.9 & $15 \cdot 4$ & 13.9 & 15.0 \\
\hline $\mathrm{Fe}_{2}^{2} \mathrm{O}_{3}^{3}---\cdots$ & 2.7 & 2.6 & .76 & 2.8 & 3.5 & 2.0 & 1.0 \\
\hline FeO & 3.7 & 3.9 & 6.4 & 4.4 & 8.6 & $8 \cdot 6$ & 8.7 \\
\hline MgO --n---n- & $2 \cdot 3$ & 2.5 & $3 \cdot 4$ & 2.0 & 6.6 & $5 \cdot 6$ & 5.6 \\
\hline $\mathrm{CaO}$ & 4.6 & 3.5 & $4 \cdot 3$ & 3.0 & 11.9 & 9.6 & 4.6 \\
\hline $\mathrm{Na}_{2} \mathrm{O}-\cdots$ & 3.8 & 4.0 & 3.1 & $2 \cdot 5$ & 2.0 & 2.6 & 2.4 \\
\hline $\mathrm{K}_{2} \mathrm{O}-\cdots$ & .52 & .76 & 1.8 & 1.8 & .14 & .00 & .10 \\
\hline $\mathrm{H}_{2}^{2} \mathrm{O}_{+}^{-}$ & $-\infty$ & -- & $-\infty$ & .12 & $-\infty$ & -- & -- \\
\hline $\mathrm{H}_{2}{ }_{2} \mathrm{O}^{+}-\cdots$ & 1.8 & 1.8 & 1.2 & 1.2 & 2.20 & 4.34 & 4.79 \\
\hline $\mathrm{TiO}_{2}-------$ & .42 & .45 & .46 & .75 & 1.2 & 1.0 & .68 \\
\hline $\mathrm{P}_{2} \mathrm{O}_{5}^{2}$ & .20 & .20 & .23 & .40 & .19 & .08 & .11 \\
\hline $\mathrm{MnO}-$ & .12 & .28 & .13 & .10 & .19 & .14 & .12 \\
\hline $\mathrm{CO}_{2}$ & 1.0 & .29 & .12 & .05 & --- & $6 \cdot 3$ & 3.00 \\
\hline \multicolumn{8}{|c|}{ C.I.P.W. norms } \\
\hline Q $-\infty-m-\infty-\infty$ & 28.22 & 26.23 & 19.68 & 31.24 & 0.94 & $13 \cdot 47$ & 23.29 \\
\hline C $-m-\infty-\infty-\infty-\infty$ & $2 \cdot 12$ & 2.49 & 1.17 & 7.47 & -- & 6.95 & 9.80 \\
\hline or - - - - & 3.08 & 4.5 & 10.66 & 10.66 & .83 & $-\infty$ & .59 \\
\hline$a b-\infty---n--n$ & 32.23 & 33.92 & 26.28 & $21 \cdot 20$ & 17.00 & 21.99 & 20.33 \\
\hline 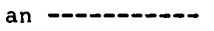 & 15.23 & 14.26 & 19.11 & 11.98 & 32.79 & 7.27 & 3.14 \\
\hline en & 5.74 & 6.24 & 8.49 & 4.99 & $16 \cdot 52$ & 13.94 & 13.96 \\
\hline 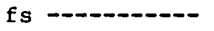 & 4.10 & 4.80 & 10.63 & 4.72 & 11.33 & 12.74 & 14.26 \\
\hline mt $---0-0--n$ & 3.92 & 3.78 & 1.10 & 4.07 & 5.10 & 2.90 & 1.45 \\
\hline $11=---0--n$ & .80 & .86 & .88 & 1.43 & 2.29 & 1.90 & 1.29 \\
\hline ap $---1--1-n$ & .48 & .48 & .55 & .95 & .45 & .19 & .26 \\
\hline 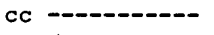 & 2.28 & .66 & .27 & .11 & -- & $14 \cdot 32$ & 6.83 \\
\hline $\mathrm{FeO} / \mathrm{Fe}_{2} \mathrm{O}_{3}$ & 1.37 & 1.50 & 8.42 & 1.57 & 2.46 & $4 \cdot 30$ & 8.70 \\
\hline Total femics - & $17 \cdot 32$ & 16.81 & 21.91 & $16 \cdot 27$ & 46.24 & 45.98 & 38.06 \\
\hline
\end{tabular}

1. Crystal tuff, Spud Mountain Volcanics $(1,220,500$ N., 368,000 E.).

2. Foliated crystal tuff, Spud Mountain Volcanics $(1,219,000$ N., 364,200 E.).

3. Amphibolitic tuff, Spud Mountain volcanics $(1,207,000$ N., 365,500 E.).

4. Sedimentary rocks, Spud Mountain Volcanics $(1,189,100 \mathrm{~N}$, , 387,800 E.).

5. Basalt, Iron King Volcanics, Nw1/4 Mayer quadrangle $(1,267,000 \mathrm{~N}$, , 434,000 E.).

6. Fine-grained marginal zone of pillow basalt, NW1/4 Mayer quadrangle $(1,265,150 \mathrm{~N} ., 403,500 \mathrm{E}$.$) .$

7. Fine-grained andesitic flow in the amygdaloidal and pillow basalt unit of the Iron King Volcanics converted to quartz-albiteepidote/clinozoisite-sericite-chlorite schist, NE1/4 Mount Union quadrangle $(1,250,100 \mathrm{~N}, 387,900 \mathrm{E.})$. 
quartz phenocrysts in a silicic magma, as the outlines of the quartz crystals are smoothly rounded, even within the deep embayments. Some complexly embayed crystals are too fragile to survive the transport and abrasion needed for rounding. The bluish color of the bipyramidal quartz may be related to $\mathrm{TiO}_{2}$ content (Deer and others, 1963, p. 207) possibly in microscopic inclusions of rutile.

Lithic chips and fragments occur sporadically in the crystal tuff; near the andesitic breccia, the abundance of volcanic fragments locally approaches that within the breccia. The most abundant lithic types are porphyritic and nonporphyritic andesitic clasts, ranging in length from $125 \mathrm{~mm}$ to more than $200 \mathrm{~mm}$. Rhyolitic fragments and rare quartzitic chips have been observed. The lithic fragments are scattered through the crystal tuff, strongly oriented with their longest dimensions parallel to $S_{2}$. Length-to-thickness ratios generally exceed 3:1 and some may exceed 8:1. North and northeast of Pine Flat, the crystal tuff locally contains abundant light-gray sericitic clasts, flattened into thin plates with a length-to-thickness ratio of 10:1. These clasts are interpreted as tectonically flattened pumice lapilli.

The bedding units within the crystal tuff are thick; individual beds range from about $1 \mathrm{~m}$ to as much as $30 \mathrm{~m}$ in thickness and normally span more than a single outcrop. This obscure large-scale bedding is best observed along stream courses that transect $\mathrm{S}_{2}$. Clear-cut evidence of graded bedding was never observed within the crystal tuff. The matrix surrounding the relict plagioclase and quartz crystals ranges from granoblastic where $S_{2}$ is poorly developed $(1,220,500$ N., 368,000 E.) to strongly lepidoblastic where schistosity is intensely developed. Chlorite, white mica, and biotite are strongly oriented and are deflected into streamlined envelopes enclosing the relict crystal. Broken and partially offset plagioclase crystals are common; the fragments rarely show appreciable rotation relative to one another.

The original nature of the matrix has been obliterated by recrystallization. The closest approximation to the original nature of the crystal tuff can be seen where it crops out along Pine Creek, a short distance south of Pine Flat $(1,220,500$ N., 368,000 E.). Foliation is poorly defined, and embayed quartz bipyramids and euhedral to rounded plagioclase phenocrysts and crystal clasts are set in a microcrystalline groundmass consisting of quartz, albite, and poorly oriented chlorite. A few widely scattered andesitic clasts can be seen. Grain size of the granoblastic matrix ranges from 0.016 to $0.04 \mathrm{~mm}$. The approximate modal composition of the groundmass is quartz, 36 percent; albite, 33 percent; chlorite, 25 percent; epidote, 4 percent; and potassium feldspar, 2 percent. Sericite, epidote-clinozoisite, and calcite occur as scattered granules and patches in the matrix but are concentrated in the saussuritized relict plagioclase. 
Andesitic breccia is exposed in the Brady Butte area only in elongate lenses northeast and southeast of Pine Flat that are interbedded with bedded andesitic tuff and in lenses south of Pine Flat that are interbedded with the dominant crystal tuff, all within the Spud Mountain Volcanics. The breccia occurs in massive bedding units 3 to $9 \mathrm{~m}$ thick that exhibit a gradual decrease upward in size of clasts that are 50 to $150 \mathrm{~mm}$ in length at the base of the unit. Interbedded crystal tuff or volcanic sandstone grades upward into laminated volcanic siltstone. Except in rare stream-bed exposures, the breccia are in general too poorly exposed in outcrop to permit widespread recognition of this graded bedding, although evidence of similar grading occurs in the breccia lens about $0.8 \mathrm{~km}$ southwest of Pine Flat. Comparison of the rock where exposed along the stream courses with typically weathered rock on the brush hillsides indicates that 50 percent of the area mapped as breccia is occupied by interbedded tuffs or fine-grained tuffaceous rocks, but massive and more resistant beds of breccia constitute most of the outcrops.

The breccias are poorly sorted, the clasts ranging in length from 25 to $300 \mathrm{~mm}$. Porphyritic andesite characterized by stubby or almost equant saussuritized plagioclase phenocrysts is the dominant lithology of the clasts, but vesicular andesite or basalt and rhyolitic clasts may be locally abundant. Felsite pebbles with oriented albite microlites and scattered microphenocrysts occur with other leucocratic clasts. Fine-grained granoblastic quartzite or chert pebbles are a minor constituent in some beds.

\section{Andesitic Tuff and Tuffaceous Rocks}

Dark-grayish-green chloritic schist and phyllite exhibiting conspicuous relict bedding in some stream-polished exposures are widely exposed in the limbs of the overturned anticline to the west and east of Pine Flat (north of $1,215,000$ N.). Fine-grained laminated amphibolite schist adjacent to the Brady Butte Granodiorite (porphyritic facies) south of $1,194,000 \mathrm{~N}$. is almost certainly the stratigraphic equivalent of the fine-grained bedded volcaniclastic rocks near Pine Flat; these schists are collectively referred to as andesitic tuff and tuffaceous rocks on the geologic map (pl. 1). Where relict stratification can be identified, it is defined by color and textural layering produced primarily by variations in size and abundance of sand-size relict plagioclase grains; although variations in the ratios of chlorite to sericite and in the relative abundance of metamorphic quartz, epidote, and calcite, delineate relict bedding at many localities. 
Foliation $\left(\mathrm{S}_{2}\right)$ is invariably evident and generally parallel to relict bedding $\left(\mathrm{S}_{1}\right)$. The finer grained schist and phyllites commonly have a pronounced fissility, cleaving readily parallel to $S_{2}$. Close scrutiny of many apparent bedded outcrops and of thin sections reveals numerous closely spaced shear dislocations that transect $\mathrm{S}_{1}$ at low angles, disrupting the sedimentary laminae and producing fissile lepidoblastic schists and phyllites composed of minute lenticles or streaks differing slightly in composition. On the geologic map (pl. 1), relict bedding is indicated only where persistent and well-defined compositional layering can be seen.

Mineral streaking and elongation of lenticular smears are visible on some foliation surfaces, imparting a lineation plunging almost parallel to the dip of $S_{2}$. Slaty and phyllitic tuffs form a small part of the andesitic tuff sequence, which may explain the rarity of cleavagebedding lineation prominent in the slate and phyllite of the younger Texas Gulch Formation. Where gently plunging small-scale folds crop out, the foliation is nearly parallel to the axial planes. Along the west margin of the quadrangle south of $1,194,000 \mathrm{~N}$., prismatic hornblende exhibits a strong preferred orientation with the long axes lying in the plane of $\mathrm{S}_{2}$.

RHYOLITIC Rocks

Rhyolitic rocks in the Spud Mountain Volcanics are exposed in only three places in the Brady Butte area: two dikelike masses crop out northwest of Battle Flat, and a larger mass southwest of Battle Flat. These rhyolitic rocks are massive, brecciated, or flow banded. The larger body consists of light-yellowish-gray foliated rhyolite that crops out on a rubble-strewn brushy ridge, forming a lenticular northeasttrending mass nearly $1,200 \mathrm{~m}$ long.

In the Cordes area about $15 \mathrm{~km}$ to the east, similar rhyolitic rocks are common in the Spud Mountain Volcanics, where some large masses cut across the structural trends of some of the associated andesitic breccias and mafic flows. Other masses are thick-bedded breccias, conformable to associated bedding structures (Anderson, 1972, p. 8).

Sedimentary Rocks

In the southeastern part of the Brady Butte area, the upper sequence of the Spud Mountain Volcanics is dominated by light-gray metasedimentary rocks that extend eastward into the Cordes area, where they separate the older andesitic tuff and tuffaceous rocks from the younger Iron King Volcanics to the north. These sedimentary beds 
are the southern extension of similar rocks exposed in the NW1/4 Mayer quadrangle (Anderson and Blacet, 1972a); in the Cordes area (Anderson, 1972), they are thicker and contain little volcanic debris, the ratio of quartz to feldspar is high, and siltstone is abundant.

In the vicinity of $1,210,000 \mathrm{~N}$., in the Cordes area, the sedimentary rocks have reached a higher grade of metamorphism; the feldspar clasts are oligoclase associated with biotite. They extend into the Brady Butte area at coordinate $1,205,000 \mathrm{~N}$. (pl. 1), where they are overlain by the younger Iron King Volcanics. In many outcrops, compositional and textural variations define conspicuous layering that probably reflects original sedimentary stratification, but increased intensity of metamorphism around the Crazy Basin Quartz Monzonite has generally destroyed the original sedimentary textures and structures. The strong preferred orientation of muscovite and biotite defines a pervasive foliation $\left(\mathrm{S}_{2}\right)$ parallel to compositional layering, probably coincident with $\mathrm{S}_{1}$ in most localities (fig. 3). Bedding symbols are used on the geologic map (pl. 1) only where the orientation of $\mathrm{S}_{1}$ is unequivocal.

Relict beds and compositional layers range in thickness from about $1 \mathrm{~m}$ in the sandstones to less than $25 \mathrm{~mm}$ in much of the siltstones. Relict clastic textures are apparent only in the sandy beds and are conspicuous in the poorly sorted feldspathic sandstones that constitute the upper part of the sequence in the vicinity of Turkey Creek. Quartz and plagioclase grains are angular to subrounded. Small-scale folding is common in the southeastern block; cleavage relations show that

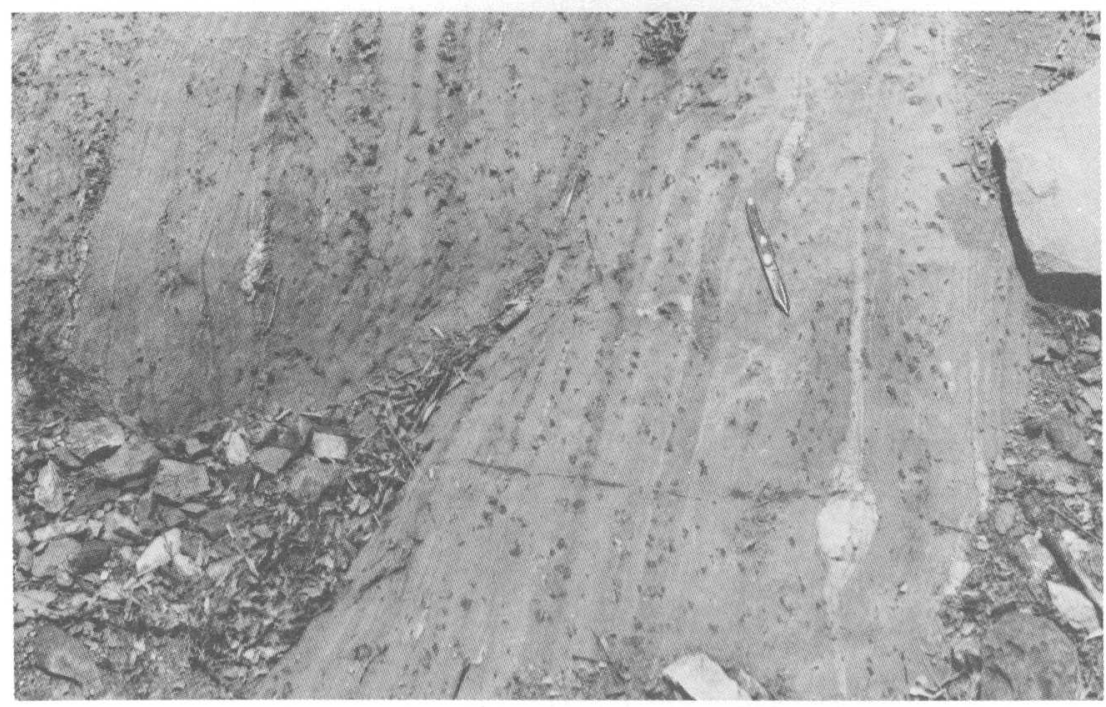

FIGURE 3.-Compositional layering reflecting stratification in sedimentary rocks in the Spud Mountain Volcanics. 
these folds are tectonic rather than sedimentary structures (fig. 4). Absence of crossbedding, ripple marks, and channeling indicate that these rocks were deposited in relatively deep water not subjected to strong tidal currents or wave action. Graded bedding and slumping in correlative rocks suggest that turbidity currents may have transported much of the sediment.

Several lines of evidence indicate that the quartz monzonite was intruded subsequent to or very late in the deformational and regional metamorphic episode of the Yavapai Series. The apparent transition between regional and contact metamorphism is closely akin to the metamorphic nodes described by James (1955) in the Precambrian terrane in northern Michigan, where thermal domes produced concentric zonal patterns in greenschist terrane on a scale similar to that in the Yavapai terrane. In Michigan, the zones are defined by the outermost occurrence of biotite, garnet, staurolite, and sillimanite. James (1955) concluded that the steep thermal gradients responsible for the closely spaced metamorphic zones resulted from magmatic intrusions less than $1 \frac{1 / 2}{2 m}$ beneath the innermost sillimanite zone. The rapid transition from greenschist metamorphism, typical of the Yavapai Series, to amphibolite facies metamorphism in the aureole

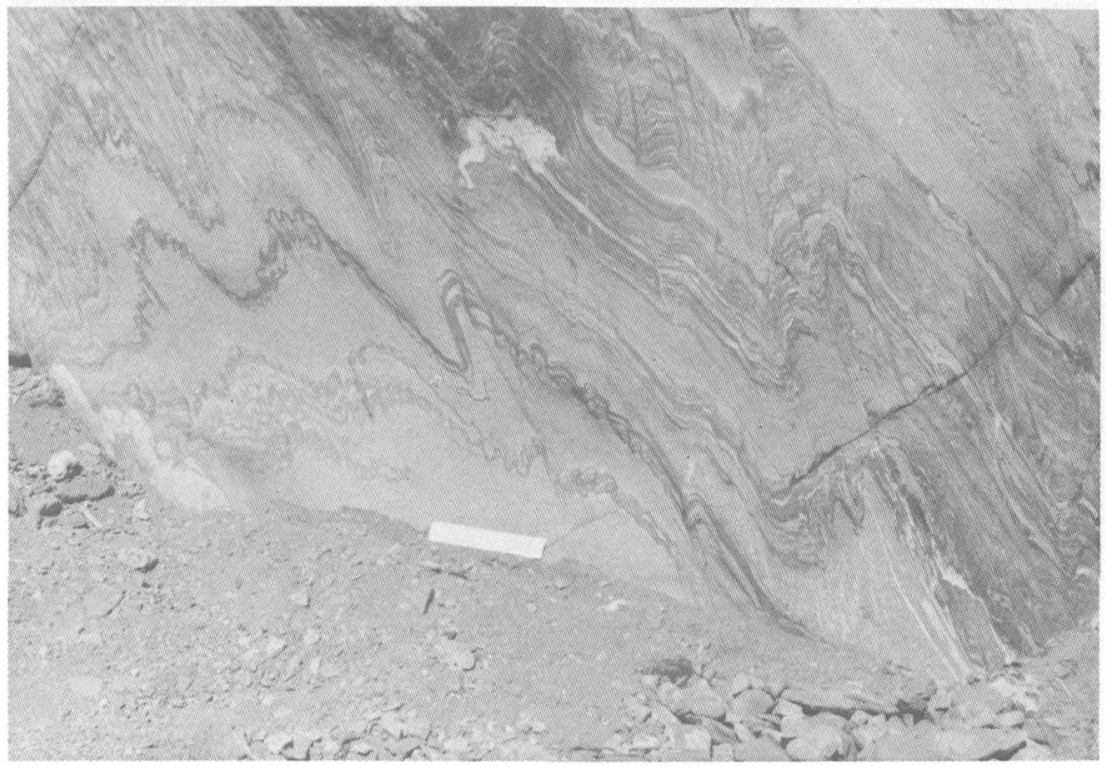

FIGURE 4.- Small scale slip folds in relict bedding $\left(\mathrm{S}_{1}\right)$ and foliation $\left(\mathrm{S}_{2}\right)$ in sedimentary rocks in the Spud Mountain Volcanics. $\mathrm{S}_{1}$ and $\mathrm{S}_{2}$ are parallel. Pronounced strain-slip cleavage $\left(\mathrm{S}_{3}\right)$, responsible for the folds, is clearly visible parallel to the axial planes of the folds. Scale is $15.2 \mathrm{~cm}$ long (1,201,800 N., 394,700 E.; pl. 1). 
surrounding the Crazy Basin Quartz Monzonite is suggestive of his model of the metamorphic nodes in northern Michigan. In the Brady Butte and Cordes areas, the inner sillimanite zone is absent.

The sequence of sedimentary rocks in the Spud Mountain Volcanics reveals three metamorphic zones indicating that temperatures increased rapidly toward the margin of the Crazy Basin Quartz Monzonite. The following mineral assemblages characteristic of these zones are: (1) Quartz + andesine (or oligocene) + garnet + biotite + muscovite; (2) quartz + andesine + garnet + staurolite \pm andalusite + biotite + muscovite; and (3) quartz + andesine + andalusite + biotite + muscovite. These metamorphic zones correspond to the lower and middle parts of the amphibolite facies. In the Brady Butte area, the regional metamorphic grade increases southward and appears to merge imperceptibly within the thermal aureole surrounding the quartz monzonite, where coarse-grained muscovite schist at the contact was intensely deformed, partially transposed to $S_{3}$, then coarsely recrystallized after movement had ceased (fig. 5).

Except for the presence or absence of the index minerals garnet, staurolite, and andalusite, the minerals and textures of the sedimentary rocks are similar in the three metamorphic zones, but minor differences occur. Pelitic schists are least abundant in the garnet zone,

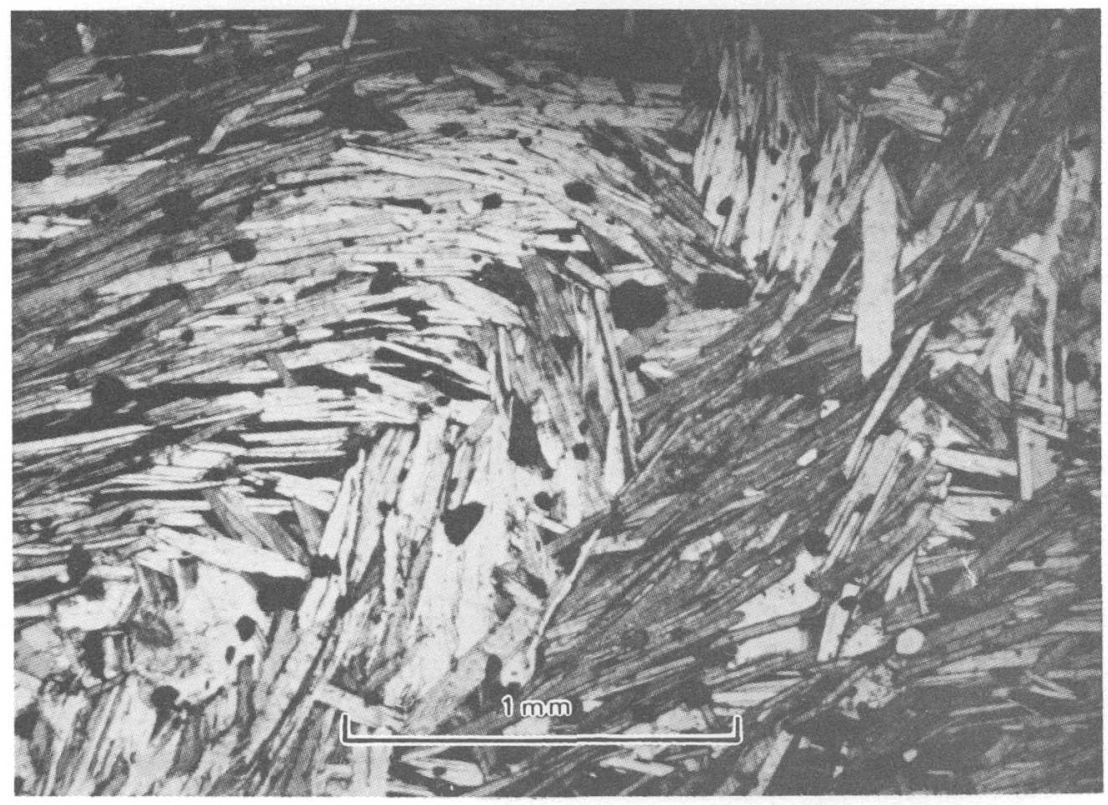

FIgURE 5.-Photomicrograph showing coarse-grained muscovite schist at contact of the Crazy Basin Quartz Monzonite. $\mathrm{S}_{2}$ was intensely deformed, partially transposed to $\mathrm{S}_{3}$, and then coarsely recrystallized after movement had ceased. Partially crossed nicols. 
which encompasses most sandy or silty facies in the upper $450 \mathrm{~m}$ of the sequence near Turkey Creek. The predominantly psammitic rocks have been converted to medium- and light-gray or olive-gray fine- to medium-grained semischists associated with lesser amounts of finegrained mica schists. Beds of favorable composition are speckled with small porphyroblasts of garnet, poikiloblastic biotite, and (or) octahedral magnetite. Biotite and muscovite are normally both present, but vary in amount. Quartz is ubiquitous, mostly in equidimensional grains associated with oligoclase or andesine. Disseminated granules of epidote are minor constituents in many beds.

Pale-green chlorite occurs in the three metamorphic zones as coarse, randomly oriented flakes or semiradiating sheaves replacing biotite or muscovite and as an alteration product of staurolite. Fine-grained muscovite is a universal alteration product of staurolite and andalusite. Tourmaline, apatite, and magnetite or hematite are common acessory minerals commonly associated with sphene, ilmenite or leucoxene, and calcite.

UNDIFFERENTIATED TUFFACEOUS ROCKS AND MAFIC FLOWS

About $1 \frac{1 / 2}{2 \mathrm{~km}^{2}}$ in the northwest corner of the area consists of undifferentiated tuffaceous rocks and mafic flows. Poor exposures or metamorphism make distinction between the other lithologic units of the Spud Mountain Volcanics difficult or impossible. Generally the rocks are dark gray to greenish black; they contain much chlorite or actinolitic hornblende.

\section{IRON KING VOLCANICS}

The Iron King Volcanics is dominantly basaltic flows that locally contain pillow and amygdaloidal structures. In its northeastern exposures, interbeds of chert are common; rhyolitic rocks appear in the southern exposures. Volcanic breccia (pl. 1) is a distinct unit at the base of the sequence that extends northward into the Cordes area (Anderson, 1972). This breccia crops out in an overturned syncline within the upper part of the Spud Mountain sedimentary sequence in the staurolite and andalusite zones, near the Crazy Basin Quartz Monzonite (pl. 2). At the north margin of the Brady Butte area, basaltic flows of the Iron King Volcanics are exposed in a small wedge in fault contact with the younger Texas Gulch Formation; this block widens appreciably northward to form the major exposures of Iron King Volcanics in the northern Bradshaw Mountains, NE $1 / 4$ Mount Union quadrangle (Anderson and Blacet, 1972a, p. 27). 
Subsequent to the fieldwork for this report, but prior to its submission for publication, Dewitt (1976) mapped in detail an area in the eastern part of the quadrangle. Dewitt concluded that the general strike of bedding in the Iron King Volcanics is westerly athwart the overall regional trend of its outcrop and that fold axes in the Iron King Volcanics plunge steeply, whereas I believe the regional strike is northnortheasterly parallel to the regional trend of the outcrop and that the folds plunge gently. Both interpretations require east-west crustal shortening and a northerly trending regional axial plane foliation. Our differences in structural interpretations, however, are major, and they cannot be resolved in this report.

Volcanic Breccia and Conglomerate

The basal contact of the Iron King Volcanics is overlain by a unit of coarse clastic and volcanic sequence of interstratified volcanic breccia, coarse sandy tuff or volcanic sandstone, lapilli tuff and tuff breccia, and, in places, blocks of pillow basalt, basaltic flows, and mixed volcanic-nonvolcanic conglomerate. This unit designated volcanic breccia and conglomerate on plate 1, is distinguished from amygdaloidal and pillow basalt of the Iron King Volcanics by the coarse clastic relict textures of the intercalated volcanic breccia and conglomerate: It grades upward by interstratification into basalt such that the contact between these lithologic units is indefinite.

Three lenslike or wedgelike bodies of this unit are shown on the geologic map (pl. 1): a main wedge above the long folded basal contact of the Iron King Volcanics; a stratigraphically equivalent basal unit that occupies the keel of an overturned syncline and is surrounded by the staurolite-bearing schists of the southeastern block; and an isolated lens $1,800 \mathrm{~m}$ long and $120 \mathrm{~m}$ thick crossing Turkey Creek that appears to lie about $900 \mathrm{~m}$ stratigraphically above the base of the Iron King Volcanics.

The largest and best exposures of this unit are along the southeastward draining tributary of Turkey Creek $(1,206,000$ N., 399,000 E.). The amphibolitic breccias are dark greenish gray distinctly mottled by color variations in the diverse clasts, commonly elongate parallel to the axes of small folds. In most outcrops, the breccia or subangular conglomerate is an unbedded chaotic mixture of angular to subrounded fragments, ranging in size from granules to blocks about $0.3 \mathrm{~m}$ in diameter (fig. $6 A$ ). Isolated vesicular bombs or pillows are enclosed in unsorted mixed volcanic-nonvolcanic breccia, strongly suggesting gravity sliding or slumping, possibly triggered by subaqueous erup- 
tions. Large lenses or beds of pillow basalt occur locally in this unit and in some areas, pillow basalt constitutes about 10 percent of this unit. Amphibolites showing relict stratification are probably volcanic sandstones or tuffs intercalated with breccia and pillow basalt. The coarsely crystalline amphibolite that occurs as clasts within the breccia and interbedded with the breccia and pillow basalt may represent mafic glassy fragments and tuffs.

Within the coarse clastic facies of the volcanic breccia and conglomerate unit, there is considerable variation in the average size of the fragments, degree of rounding and sorting, and relative proportion of types of clasts. Coarse chaotic breccias of probable slump origin occur widely, as do poorly sorted, finer grained breccias that probably represent mafic lithic lapilli tuffs admixed with silicic volcanic and nonvolcanic detritus in variable amounts (fig. $6 B$ ). Clasts fall into three categories, in order of decreasing abundance: (1) dark-greenish-gray amphibolite, with or without biotite and almandine; (2) felsite containing bipyramidal quartz phenocrysts; and (3) quartzite and (or) chert, partially replaced by ankerite carbonate.

The quartzose pebbles are white to dark-gray fine-grained metachert(?). The average diameter of the quartz grains ranges from 0.06 to $0.3 \mathrm{~mm}$. The fine-grained siliceous clasts $(0.06-0.15 \mathrm{~mm})$ correspond in average grain size to metacherts in the biotite and garnet metamorphic zones of northern Michigan (James, 1955, p. 1462). The granoblastic quartz mosaic typically constitutes more than 90 percent of the quartzose pebbles; accessory minerals commonly present are: reddishbrown biotite, muscovite, grunerite, calcite, apatite, and hematite. The variation of grain sizes in the various fragments seems to indicate that the quartzose clasts are derived from several sources, including chert and possibly quartzite.

Abundant light-gray felsite clasts consist of a fine-grained granoblastic mosaic of intergrown quartz and untwinned andesine or oligoclase. Some of the felsitic clasts contain quartz phenocrysts about $1 \mathrm{~mm}$ in diameter that appear similar to clasts in silicic volcanic or hypabyssal rocks within the Spud Mountain Volcanics and Iron King Volcanics. Their similarity suggests that the felsite and quartz porphyry clasts were probably derived from rhyolitic or dacitic flows or domes formed as part of the complex volcanism recorded in the Iron King Volcanics. These felsitic clasts outnumber the quartzose pebbles.

Mafic clasts contain blue-green amphibole with the pleochroic scheme: $\mathrm{X}=\tan , \mathrm{Y}=$ green, $\mathrm{Z}=$ blue green or greenish blue; the subhedral prisms range in length from 0.5 to $2.0 \mathrm{~mm}$. Subordinate olivegreen biotite generally accompanies the amphibole. Incipient retrograde metamorphism is suggested by scattered unoriented plates or sheaves of chlorite that cut biotite and amphibole. The coarse-grained 

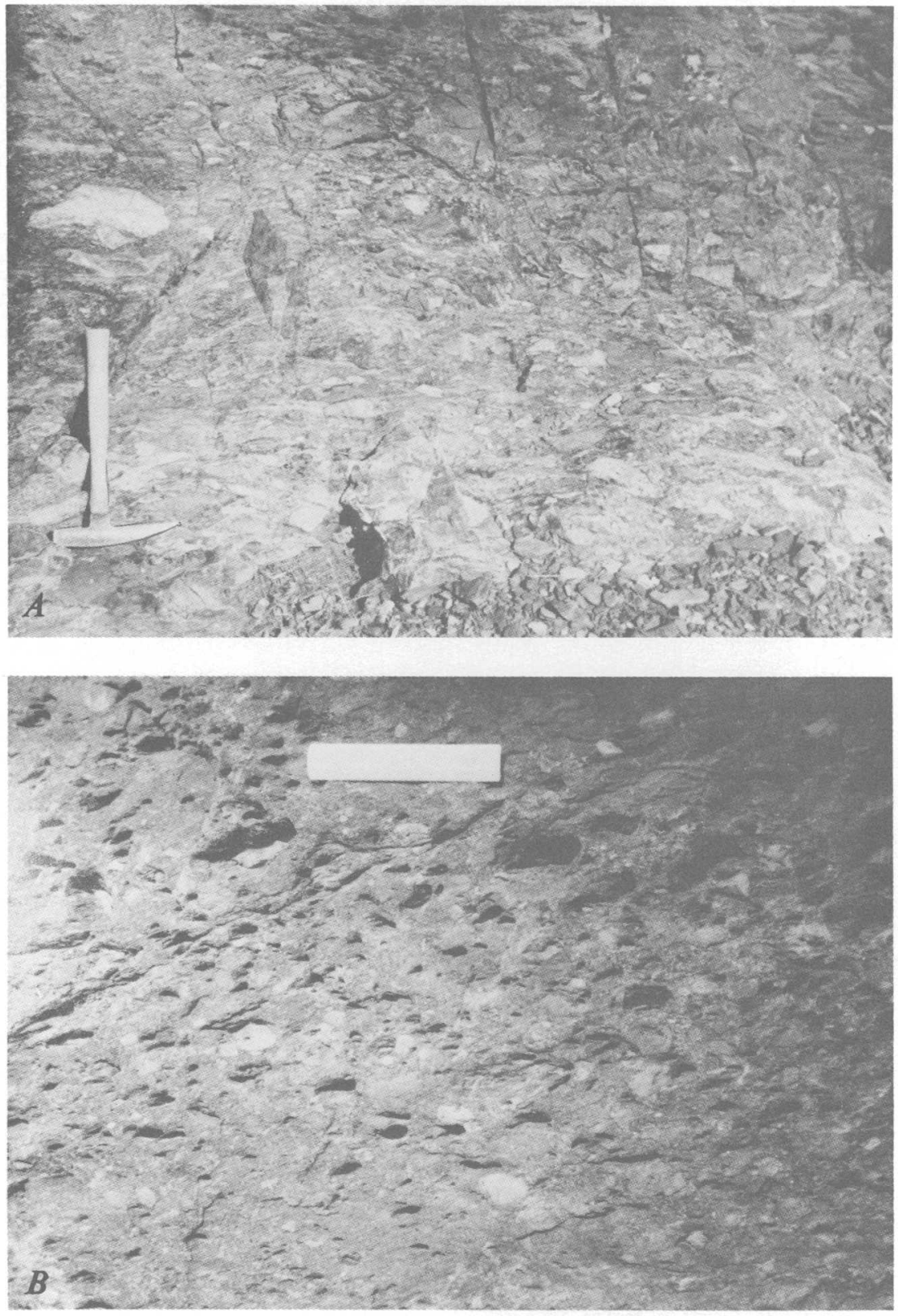

- Figure 6.-Volcanic rocks in the Iron King Volcanics. A, Volcanic breccia. Coarse fragmental texture is made conspicuous by unusual abundance of silicic volcanic ' clasts (1,206,000 N., 399,000 E.; pl. 1). B, Volcanic conglomerate. Rounded light-colored chert and felsite pebbles mixed with darker angular volcanic clasts. Scale is $15.2 \mathrm{~cm}$ long. 
mafic minerals are set in a fine-grained granoblastic matrix of andesine and (or) oligoclase. Quartz is absent or a minor constituent. Granular epidote is sparse and associated with accessory sphene, calcite, apatite, and magnetite.

The apparent absence of relict textures in the mafic clasts, except for occasional vesicular bombs or pillows, contrasts with the felsite clasts that in part exhibit well-preserved relict porphyritic texture. The total destruction of relict textures in the mafic clasts suggests that the original rocks were microcrystalline or glassy basaltic lapilli and therefore highly susceptible to metamorphic crystallization.

Amygdaloidal and Pillow Basalt

The thickest unit of the Iron King Volcanics, designated "amygdaloidal and pillow basalt" on the geologic map (pl. 1), is composed of interstratified mafic tuff, massive to amygdaloidal basaltic flows, and pillow basalts. The tuffaceous rocks are moderately to well foliated, but textural and compositional layering that is distinctly bedded is rare except in a few thin zones of silicified tuff or chert. The interbedded cherts, zones of pillow basalt and volcanic breccia, gross lithologic variations within the tuffs, and orientation of the depositional contact at the base of the formation all indicate stratification striking northeast and inclined steeply to the northwest.

In the absence of relict structures such as amygdules or pillows, there is no simple way of determining if a given layer of amphibolite represents a mafic flow or sill, palagonite tuff, or other volcaniclastic rock. Intensely foliated amphibolitic and chloritic schists, generally showing vague layering, are interpreted as andesitic to basaltic rocks.

A subaqueous environment is clearly indicated by the wide distribution of pillow basalts. In the Brady Butte area, it is rare to find relict pillow structure so well preserved and exposed that pillow tops can be distinguished. Reliable top determinations were possible at only two localities $(1,213,700$ N., $388,800 \mathrm{E}$., and at 1,183,500 N., 377,700 E., fig. 7 ), but unequivocal pillow structures were observed at a dozen widely separated localities. Identification of relict pillow structure is usually positive only in fresh and polished outcrops along the larger intermittent streams.

Excellent exposures near 1,213,700 N., 388,800 E. reveal pillows ranging in length from 0.2 to $1.2 \mathrm{~m}$, with length-thickness ratios between 2 and 3 . Dark-gray rims about $1 \mathrm{~cm}$ thick surrounding the pillows possibly are relict glassy selvages. Small relict amygdules appear in the interiors of the pillows. The convex and cuspate undersides of the pillows at this locality face west, indicating that, at least 
locally, the northwest-dipping stratification in the unit is overturned toward the east.

Pillow structures are exposed in basalt about $1,000 \mathrm{~m}$ from the Crazy Basin Quartz Monzonite (1,183,500 N., 377,700 E.); the tops of the pillows face northwest. Cherty material or calcite commonly fills the spaces between the pillows; the silica and calcium carbonate were deposited shortly after the outpouring of the pillow basalts.

Chemical analyses of seven mafic flows from the Mayer and Mount Union quadrangles (Anderson and Blacet, 1972a, p. 29) show a range in composition from basalt to basaltic andesite with a $\mathrm{K}_{2} \mathrm{O}$ content ranging from 0.00 to 0.17 percent. The basaltic flows in the Brady Butte area also are low in $\mathrm{K}_{2} \mathrm{O}$.

\section{RHYOLITE}

A lenticular mass of rhyolite is exposed in the southern part of the area of Iron King Volcanics, west of the De Soto mine, where it has a maximum width of $610 \mathrm{~m}$. The light gray of the rhyolite contrasts sharply with the deeper brown tones of the enclosing mafic volcanic rocks. Quartz-albite-sericite schist predominates in the rhyolite, and

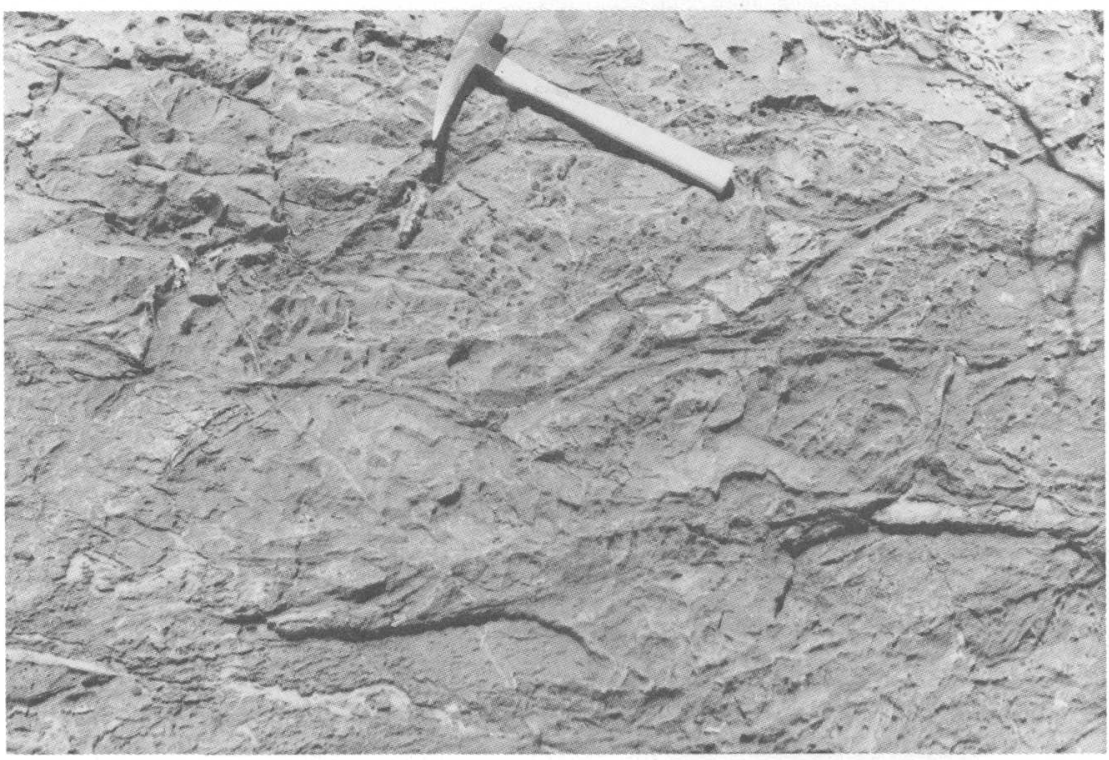

FIGURE 7.-Relict pillows in amphibolite-facies metabasalt of the Iron King Volcanics. Cuspate undersides indicate that the pillows are right side up. Thin pillow skins are weathered in relief; note chert filling below the hammer handle $(1,183,500 \mathrm{~N} ., 377,700$ E.; pl. 1). 
the foliation is conformable to that in the adjacent amphibolite. This rhyolite contains rounded complexly twinned relict plagioclase crystals and (or) crystal fragments set in a finer grained lepidoblastic matrix of brown biotite and anhedral quartz and andesine associated with scattered grains or patches of epidote, calcite, and magnetite. Where foliation is not accompanied by pronounced fissility, the rhyolite is resistant to weathering and forms conspicuous light-colored outcrops with a hackly cleavage parallel to $\mathrm{S}_{2}$. Massive rhyolite of this type crops out along the high ridge southwest of the Swastika mine. Studies by microscopy revealed the presence of lath-shaped albite phenocrysts, 0.1 to $0.35 \mathrm{~mm}$ long, in a microcrystalline xenoblastic groundmass of quartz, albite, and potassium feldspar. There is no evidence of cataclasis, and the oriented plagioclase laths reveal a relict flow structure that must have developed in a rhyolitic flow, shallow sill, or a pumiceous tuff containing plagioclase phenocrysts and microlites that were oriented during compaction.

Ferruginous Chert

Narrow veinlike silicic rocks occur widely in the Iron King sequence of amygdaloidal and pillow basalt, where they form conspicuous and narrow bold outcrops. Some are clearly ferruginous chert intertonguing with the associated lavas that are well exposed in the northeastern part of the area (pl. 1, 1,214,000-1,220,000 N., 390,000-394,000 E.). The most numerous outcrops are massive, white to dark gray, and somewhat irregular in outline. Some of these quartz bodies, designated "quartz lenses, pods, and veins" on the geologic map (pl. 1), are clearly replacements, others may represent podlike deposits of gelatinous silica related to subaqueous volcanism.

These siliceous and commonly ferruginous rocks generally crop out in elongate zones or lenticular bodies, $1 \mathrm{~m}$ to more than $30 \mathrm{~m}$ thick, that tend to parallel the planar structure in the adjacent rocks. Some of these zones can be traced along the strike for about $1,000 \mathrm{~m}$ or more and are normally conformable to the gross stratification in the Iron King Volcanics.

Distinct layering is generally absent from the iron-poor quartzose bodies in the amphibolites south of $1,205,000 \mathrm{~N}$.; recrystallization and redistribution of silica probably has obliterated or greatly obscured any bedding originally present. Banded iron formation and some ferruginous chert, quartz-rich layers alternating with layers rich in magnetite and (or) hematite, being less susceptible to the annealing effect of amphibolite facies metamorphism, may retain much of their sedi- 
mentary appearance. Laminated magnetite-hematite taconite occurs near the De Soto mine in a northeast-trending zone; one sample contained 28.3 percent $\mathrm{Fe}, 0.9$ percent $\mathrm{Mn}$, and 0.2 percent $\mathrm{TiO}_{2}$ with iron present as 25 percent magnetite and 15 percent hematite (Harrer, 1964, p. 104).

The average diameter of quartz grains in typical granoblastic chert beds increases from about 0.06 to $0.8 \mathrm{~mm}$ in the northern part of the Brady Butte area to 0.15 to $0.20 \mathrm{~mm}$ in the staurolite zone about $500 \mathrm{~m}$ from the Crazy Basin Quartz Monzonite (1,187,000 N., 384,700 E.). Northward into the $\mathrm{NW}^{1 / 4}$ Mayer quadrangle, the microcrystalline quartz in the chert beds has a grain size ranging from 0.02 to $0.09 \mathrm{~mm}$, averaging about $0.04 \mathrm{~mm}$, close to the size of associated magnetite crystals (Anderson and Blacet, 1972a, p. 25). The southward increase in the average size of quartz grains corresponds closely to an analogous progression observed in northern Michigan, where the average quartz diameter in relatively pure chert increases from $0.05 \mathrm{~mm}$ in the biotite zone to $0.20 \mathrm{~mm}$ in the staurolite zone (James and others, 1961, p. 75).

The iron in the cherts is present as magnetite and hematite; commonly magnetite is the more abundant. Both minerals are variable in grain size from one sample to another; generally the size increases with the coarseness of the associated quartz. Where the quartz has recrystallized coarsely or redistributed with destruction of relict sedimentary lamination, iron commonly occurs as specularite in crosscutting veinlets.

The relatively restricted extent and common lenticularity of the ferruginous chert are consistent with a probable origin as chemical precipitates, interleaved with fine-grained clastic or pyroclastic sediments that were precipitated from bottom waters enriched in silica and iron, and to some extent, in manganese, discharged from subaqueous springs or leached from the mafic volcanic rocks during the Iron King volcanism.

Areas of intense alteration, mapped as "silicified and sericitized rocks" on the geologic map (pl. 1), are concentrated in the Iron King Volcanics where the light-colored quartz-sericitic rock contrasts sharply with the enclosing mafic volcanic rocks. The largest area of intense alteration crops out near the De Soto copper mine $(1,195,500 \mathrm{~N}$., $387,500 \mathrm{E}$.) and is characterized by limited zones of microcrystalline pale-pink rock. Petrographic and X-ray studies have revealed that this peculiar rock consists of fine-grained optically positive triclinic potassium feldspar, tentatively identified as isomicrocline (Winchell and Winchell, 1951). Fine granular quartz is intergrown with potassium feldspar and occurs as veinlets. Sericite is widely scattered through this feldspar-quartz intergrowth. 


\section{OLDER PLUTONIC ROCKS}

The Brady Butte Granodiorite, the dominant pluton in the area, forms a major north-northeast-trending ridge transecting the western half of the Brady Butte area. It is in both fault and depositional contact with the younger Texas Gulch Formation (pl. 1). The southwestern part of the pluton consists of a porphyritic facies with a transitional zone eastward into the major pluton. A small stock of quartz diorite is exposed adjacent to the fault along the southern belt of Texas Gulch Formation.

\section{BRADY BUTTE GRANODIORITE}

The Brady Butte Granodiorite is well exposed in the prominent landmark, Brady Buttes. About $1.5 \mathrm{~km}$ north and northeast of the summit of the Butte, Wolf Creek is deeply incised into the granodiorite, providing continuous exposures across the outcrop width of the pluton. The Brady Butte Granodiorite is well exposed along Turkey Creek and Tuscumbia Creek in the west-central and southwestern parts of the Brady Butte area.

The Brady Butte Granodiorite is medium to coarse grained, the average diameter of the quartz and plagioclase crystals ranging from 3 to $7 \mathrm{~mm}$. Metamorphic foliation is developed throughout the exposed granodiorite, and mylonitic textures are locally well developed. Fresh specimens from outcrops in the major stream beds are light to medium gray with an olive hue imparted by the fine granular epidote in the plagioclase. The weathered rock is light yellowish gray in most outcrops.

The ridgelike surface configuration reflects the relatively resistant character of the Brady Butte Granodiorite. Large rounded and boulderlike exposures are common, especially on the higher ridges. Where metamorphic foliation is marked, as in the rock exposed on the western slopes of Brady Butte and north of its summit, decomposition is more advanced and outcrops are fewer in number. A few poorly defined shear zones within the less foliated interior of the granodiorite block are accentuated by weathering.

Hand specimens of the Brady Butte Granodiorite are characterized by a dull appearance imparted by alteration and recrystallization, largely a result of regional metamorphism. Biotite forms fine granular clots, or deformed, partly recrystallized grains. The plagioclase has been made turbid by saussuritization. Large quartz crystals are highly strained and commonly are granulated to such a degree as to lose their vitreous luster. 
Throughout much of the interior of the central gneissic block, where foliation is relatively poorly developed, the Brady Butte Granodiorite is only slightly modified by granulation and recrystallization. Plagioclase occurs as euhedral or subhedral elongate crystals, largely enclosed in anhedral quartz. The original plagioclase is altered to albite clouded with sericite and fine granular epidote or clinozoisite. Rims of clear untwinned albite commonly envelop the saussuritized plagioclase, and grains of calcite are scattered along the albite rim. Quartz forms large strained anhedra that have been partially recrystallized to finegrained granoblastic mosaic of unstrained grains. Microcline occurs interstitially as irregular grains. Absence of well-formed phenocrysts or porphyroblasts of microcline help distinguish the equigranular texture typical of the Brady Butte from its porphyritic facies exposed in the southwestern part of the area. Biotite predominates over sericite; it is tan to olive green under the microscope and forms fine granular aggregates associated with epidote, magnetite, and sphene.

Modal analyses of six samples of Brady Butte Granodiorite were made by point-counting sawn slabs stained with cobaltinitrite and amaranth solution using the techniques of Laniz and others (1964). Approximately 1,000 to 2,000 points were counted in each slab. The modal analyses all plot in the granodiorite field of the classification scheme of Bateman and others (1963) (fig. 8). The average mode of the six samples is: Quartz, 27.2 percent; saussuritized plagioclase, 43.5 percent; potassium feldspar, 15.5 percent; dark minerals (mostly biotite), 13.8 percent. The chemical and normative composition of the foliated, massive, and porphyritic phases of the Brady Butte Granodiorite is given in table 2.

The porphyritic facies of the Brady Butte Granodiorite is exposed in the southwestern corner of the Brady Butte area, where it intrudes the crystal tuff and fine-grained andesitic tuff of the Spud Mountain Volcanics. A migmatitic zone is well developed in hornfelsic tuffs and amphibolites near the granodiorite contact south of Battle Flat. A nonporphyritic marginal facies crops out along the northeast-trending segment of the contact south from Battle Flat; it is a medium-grained quartz diorite containing numerous mafic inclusions oriented parallel to the intrusive contact and $\mathrm{N} .50^{\circ} \mathrm{E}$. foliation in the adjacent Spud Mountain Volcanics. Within $100 \mathrm{~m}$ east of the intrusive contact, the marginal facies grades into the predominant coarse-grained porphyritic facies.

The porphyritic granodiorite facies appears to constitute the northern end of an elongate pluton, $19.3 \mathrm{~km}$ long and about 1.5 to $3 \mathrm{~km}$ wide, that has been intruded parallel to the north-northeast striking foliation and stratification in the metamorphosed country rock. Three kilometers south of the Mount Union quadrangle, the porphyritic 
granodiorite is intruded by a stock of early Tertiary(?) quartz diorite; the porphyritic granodiorite continues for about $9 \mathrm{~km}$ south of the stock (Jaggar and Palache, 1905). The contact between the porphyritic facies and typical Brady Butte Granodiorite is approximately located where microcline phenocrysts are conspicuous. The coarse-grained porphyritic granodiorite generally forms light-yellowish-gray, rounded, and bouldery outcrops. Foliation is absent or barely perceptible in most outcrops, and the large microcline crystals show no obvious preferred orientation.

The following mineralogical composition was determined by counting 1,000 points on a stained slab of typical porphyritic granodiorite, collected about $100 \mathrm{~m}$ or more east of the intrusive contact with the Spud Mountain Volcanics, in the extreme southwest corner of the quadrangle (analyzed sample 3, table 2): quartz, 23 percent; potassium feldspar, 19 percent; sodic plagioclase, 51 percent; total femic constituents, mostly biotite, 8 percent.

The distinctive porphyritic character of the granodiorite exposed at Tuscumbia Mountain is most apparent at the outcrop, where equant megacrysts of perthitic microcline, generally 1.5 to $3 \mathrm{~cm}$ in diameter,

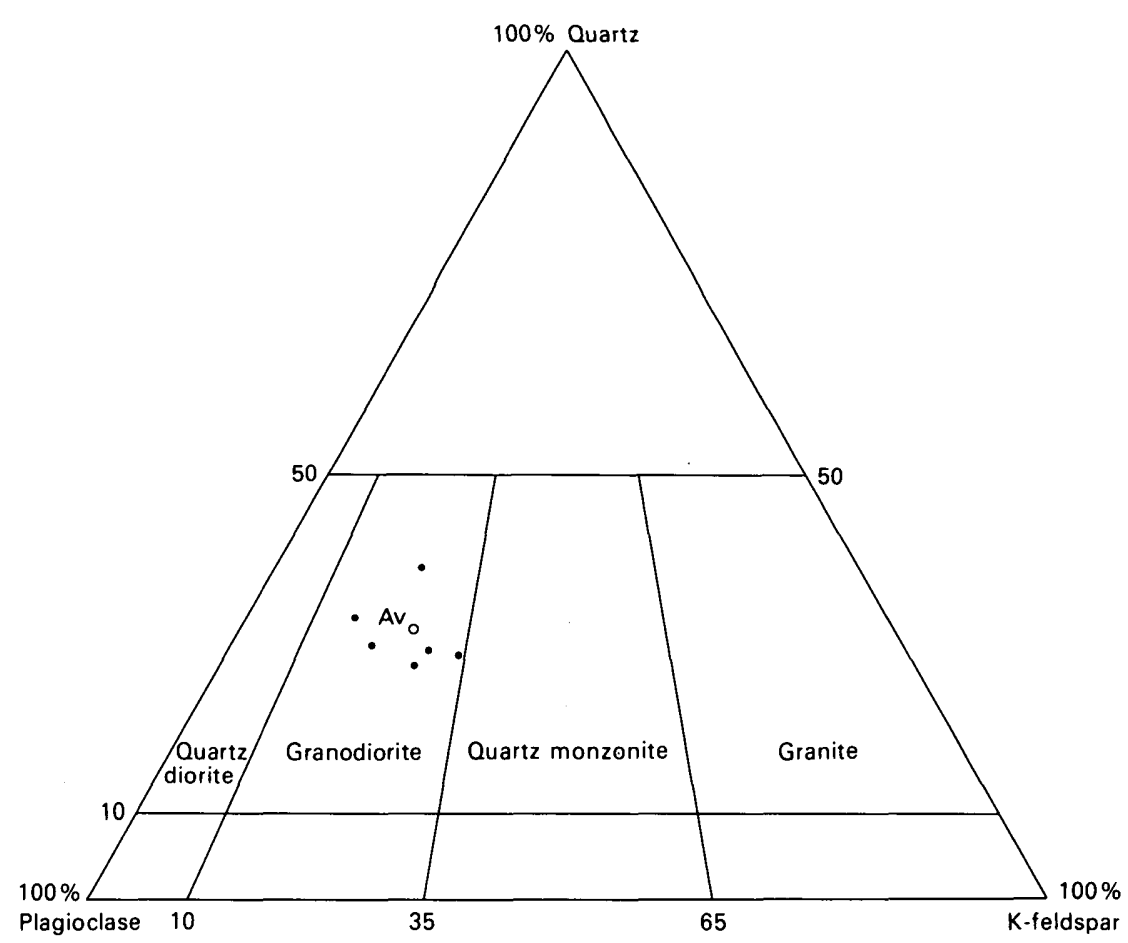


Table 2.--Chemical analyses and C.I.P.W. norms of the Brady Butte Granodiorite and Crazy Basin Quartz Monzonite [Chemical analyses by rapid rock method; analysts: Paul L. D. Elmore, Lowell Artis, Samuel Botts, Gillison Chloe, John Glenn, and Hezekiah Smith]

\begin{tabular}{|c|c|c|c|c|c|c|}
\hline & 1 & 2 & 3 & 4 & 5 & 6 \\
\hline \multicolumn{7}{|c|}{ Chemical analyses (in weight percent) } \\
\hline $\mathrm{SiO}_{2}$ & 70.5 & 70.8 & 70.6 & 71.4 & 73.5 & 73.5 \\
\hline $\mathrm{Al}_{2} \mathrm{O}_{3}$ & 14.4 & 15.1 & 15.5 & 14.6 & 14.3 & 14.0 \\
\hline $\mathrm{Fe}_{2} \mathrm{O}_{3} \cdots$ & .84 & 1.0 & 1.1 & 1.1 & .42 & .4 \\
\hline FeÓ & 1.6 & 1.6 & 1.9 & 1.3 & .80 & 1.0 \\
\hline Mgo - - - - - - & 1.2 & .75 & .16 & .58 & .23 & .10 \\
\hline $\mathrm{CaO}$ & 2.0 & 1.7 & 2.3 & 1.9 & 1.1 & 1.3 \\
\hline $\mathrm{Na}_{2} \mathrm{O}$ & 4.0 & 3.7 & 3.8 & 3.6 & $3 \cdot 3$ & 3.0 \\
\hline $\mathrm{K}_{2} \mathrm{O}$ & 3.2 & 3.3 & 2.9 & 3.6 & 4.9 & 4.8 \\
\hline $\mathrm{H}_{2} \mathrm{O}_{+}^{-}$ & .06 & .13 & .13 & .13 & .08 & .09 \\
\hline $\mathrm{H}_{2} \mathrm{O}^{+}$ & .79 & .78 & .70 & .85 & .69 & .28 \\
\hline $\mathrm{TiO}_{2}$ & .21 & .24 & .30 & .23 & .11 & 1.0 \\
\hline $\mathrm{P}_{2} \mathrm{O}_{5}^{2} \cdots$ & .09 & .31 & .25 & .27 & .35 & .31 \\
\hline MnO & .07 & .06 & .08 & .07 & .03 & .03 \\
\hline $\mathrm{CO}_{2}$ & 1.00 & .12 & .12 & .18 & .09 & .19 \\
\hline \multicolumn{7}{|c|}{ C.I.P.W. norms } \\
\hline Q -- - & 31.01 & 32.43 & 32.34 & 32.55 & 33.69 & 36.17 \\
\hline C - - & 3.26 & 3.39 & 2.81 & 2.40 & 2.62 & 2.69 \\
\hline or - & 18.93 & 19.61 & 17.19 & 21.34 & 29.01 & 28.39 \\
\hline 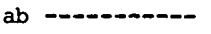 & 33.88 & 31.48 & 32.25 & 30.56 & 27.97 & 24.41 \\
\hline an $-\cdots$ & 3.02 & 5.68 & 9.05 & 6.55 & 2.61 & 3.23 \\
\hline en - - - - - & 2.99 & 1.88 & .40 & 1.45 & .57 & .25 \\
\hline fs - - & 2.03 & 1.84 & 2.24 & 1.23 & 1.00 & -- \\
\hline mt --N-- & 1.22 & 1.46 & $1.60^{\circ}$ & 1.06 & .61 & .42 \\
\hline il - - & .40 & .49 & .57 & .44 & .21 & 1.90 \\
\hline ap --n-- & .21 & .74 & .59 & .64 & .83 & .74 \\
\hline cc - - - & 2.28 & .27 & .27 & .41 & .21 & .43 \\
\hline $\mathrm{FeO} / \mathrm{Fe}_{2} \mathrm{O}_{3}$ & 1.91 & 1.60 & 1.73 & 1.18 & 1.91 & 2.50 \\
\hline Total femics - & 9.13 & 6.64 & 5.68 & 5.77 & 3.43 & 3.85 \\
\hline
\end{tabular}

1. Foliated granodiorite, Brady Butte Granodiorite $(1,224,600$ N., 378,900 E.).

2. Brady Butte Granodiorite $(1,200,000$ N., 374,600 E.).

3. Brady Butte Granodiorite, porphyritic facies $(1,182,800 \mathrm{~N},, 362,000 \mathrm{E}$ ).

4. Brady Butte Granodiorite, porphyritic facies $(1,188,100 \mathrm{~N}$., 370,600 E.).

5. Crazy Basin Quartz Monzonite $(1,183,000$ N., 383,800 E.).

6. Crazy Basin Quartz Monzonite $(1,183,400$ N., 383,800 E.).

FIGURE 8.-Modal composition of six samples and average mode of the Brady Butte Granodiorite by the plutonic rock classification used in this report. After Bateman and others, 1963. 
are widely scattered through coarsely crystalline rock. These microcline crystals have irregular margins suggestive of porphyroblasts, but in thin section are seen to be irregularly replaced by albite-oligoclase $\left(A n_{8-17}\right)$. Rounded masses of myrmekitic sodic plagioclase commonly occur as outgrowths from subhedral plagioclase into adjacent microcline megacrysts or interstitial grains, producing scalloped boundaries between the two feldspars. Granular aggregates or veinlets of albite or oligoclase, much of it myrmekitic, also crosscut or completely enclose irregular patches of microcline in optical orientation with adjacent grains, suggesting widespread replacement of potassium feldspar by sodic plagioclase. Anhedral grains of twinned microcline and microcline-perthite are common in the interstices between the subhedral plagioclase.

Small pegmatite dikes and lenses are fairly common in and adjacent to the porphyritic facies of the Brady Butte Granodiorite exposed in Tuscumbia Mountains; none occur in the typical Brady Butte Granodiorite.

Samples of Brady Butte Granodiorite were collected in two localities by L. T. Silver and T. W. Stern for isotopic dating using zircons. One sample came from near Battle Flat, well within the typical Brady Butte Granodiorite; the second was collected in the porphyritic facies of the Brady Butte Granodiorite near the contact with the Spud Mountain Volcanics. The two chords representing the zircon families yield similar ages near 1,770 \pm 10 m.y., indicating that there is no substantial age difference in the two facies of the Brady Butte Granodiorite (Anderson and others, 1971, p. C13).

\section{QUARTZ DIORITE}

A small stock of medium-grained hypidiomorphic-granular biotite quartz diorite is exposed in an area of about $0.3 \mathrm{~km}^{2}$ on the eastern slope of the brush ridge dividing Tuscumbia Creek from Bear Creek, about $1.5 \mathrm{~km}$ southeast of Battle Flat. This irregular-shaped stock is surrounded by Brady Butte Granodiorite, except on the eastern side, where it is truncated by the fault separating the Brady Butte from the Texas Gulch Formation. Foliation parallel to that in the adjacent granodiorite is locally conspicuous in the quartz diorite, suggesting a similar tectonic history. Poor exposures obscure the contact relations between the quartz diorite and enclosing granodiorite, which may be gradational over a distance of 1 to $30 \mathrm{~m}$. The quartz diorite may represent a more mafic comagmatic relative of the Brady Butte Granodiorite, or it might date from a distinctly younger plutonic episode.

The quartz diorite is intensely epidotized; subhedral plagioclase constitutes about 45 percent of the rock, quartz about 30 to 35 percent; 
olivine-green biotite makes up the remaining 20 percent. The original plagioclase has been completely altered to oligoclase, crowded with subhedral to euhedral granules and massive aggregates of epidote accompanied by small flakes of muscovite and biotite. Some of the biotite shows little evidence of deformation; its occurrence as coarse anhedral crystals interlocked in irregular aggregates may have resulted from complete recrystallization during the amphibolite-facies metamorphism that affected the Big Bug Group in the southern part of the quadrangle. Poorly developed deformation lamellae and undulous extinction are characteristic of the quartz, although the overall fabric is not cataclastic. Common accessory minerals are apatite, magnetite, sphene, zircon, and tourmaline.

\section{TEXAS GULCH FORMATION}

The Texas Gulch Formation, defined by Anderson and Creasey (1958, p. 28-30), is composed of alternating belts of bedded rhyolitic tuff and purple to gray slate that crop out in a band about $760 \mathrm{~m}$ wide in the Shylock fault zone in the western part of the Mingus Mountain quadrangle. The formation in Texas Gulch, the type locality, is so intensely deformed that the abrupt termination of a particular slate or tuff band cannot be distinguished as a fold, a lens, or a gross boudin. The east and west boundaries of the formation are faults.

Light- to dark-gray slate forms the core of an anticline in the northwest quadrant of the $\mathrm{NE}^{1 / 4}$ Mount Union quadrangle (pl. 2; Anderson and Blacet, 1972a, pl. 1) and extends northward into the Prescott quadrangle, forming wider exposures consisting in part of ferruginous chert and pebble-conglomerate beds. The structural relations prove that these slaty beds are older than the overlying basalts and that they represent the basal part of the Green Gulch Volcanics. Krieger (1965, pl. 1) designated these slaty rocks as the Texas Gulch Formation. Isotopic dating has now disproved earlier correlation of the slate beds with the Texas Gulch Formation (Anderson and others, 1971).

The Texas Gulch Formation is exposed in the NE $1 / 4$ Mount Union quadrangle as a faulted sliver, only $91 \mathrm{~m}$ wide in outcrop at its northern end (pl. 2). On the east, the Texas Gulch Formation is in fault contact with the Iron King Volcanics, on the west, with the Spud Mountain Volcanics, forming a fault block that widens appreciably toward the southern margin of this quarter quadrangle (Anderson and Blacet, 1972a, p. 44 and pl. 1).

The stratigraphic position of the Texas Gulch Formation is revealed only in the Brady Butte area, where Blacet (1966) found that the formation is in depositional contact with the underlying Brady Butte Granodiorite. Radiometric dating (Anderson and others, 1971) proves 
that the Brady Butte Granodiorite is younger than the Big Bug Group; the Texas Gulch Formation therefore is not a part of the Big Bug Group but a distinctly younger formation that accumulated after episodes involving deformation of the Big Bug Group and younger plutonism.

In the Brady Butte area, the Texas Gulch Formation crops out in two long belts trending N. $5^{\circ}-30^{\circ} \mathrm{E}$., the limbs of a faulted and partly overturned anticline, with the Brady Butte Granodiorite forming its core (pls. 1, 2). Small-scale overturned folds are superimposed on this major anticlinal structure such that at any single outcrop, relict crossbedding must be found to determine if the bedding at that place is overturned.

Along the eastern limb, quartz-sericite schist and phyllite in the Texas Gulch Formation extends southward into the Crown King quadrangle. South of Turkey Creek (1,205,000 N., 379,000 E.), the Brady Butte Granodiorite is faulted against a persistent zone of deformed pebble conglomerate within the Texas Gulch Formation. The eastern limb of this formation is separated from the Iron King Volcanics by a zone of intense shearing that constitutes the largest fault in the Brady Butte area.

Southward from a point $1.29 \mathrm{~km}$ southwest of Brady Butte $(1,218,500$ N., 374,000 E.), the western limb of the Texas Gulch Formation is bounded by steeply dipping faults that strike nearly northward. The point of convergence of these two faults at the east margin of Battle Flat $(1,203,000$ N., 371,200 E.) marks the south end of the western belt. North of locality 1,218,500 N., 374,000 E., the fault bounding the Brady Butte Granodiorite on the west diverges from the contact, extending north-northeastward in schist and phyllite of the Texas Gulch Formation.

West, north, and northeast of Brady Butte, arkosic sandstones and conglomerates of the Texas Gulch Formation are in depositional contact with the underlying gneissic granodiorite. Where well exposed along the northeastern wall of the canyon of Wolf Creek, the surface trace of the base of the unconformity has a general northwest trend, and can be followed for a distance more than $3 \mathrm{~km}$ downstream to the confluence with Little Wolf Creek (1,226,500 N., 378,000 E.). About 1.5 $\mathrm{km}$ north of Brady Butte, in the canyon of Wolf Creek, tight folding of the unconformity is revealed and reflected by the map pattern (pl. 1), but northeast of Brady Butte, the folds in the unconformity diminish in amplitude and the basal sedimentary contact is remarkably well preserved.

CONGLOMERATE

The trace of the unconformity at the base of the Texas Gulch Formation is approximately $9.6 \mathrm{~km}$ in length, and for about half of this 
distance, the granodiorite is overlain by a thin sheet of boulder to pebble conglomerate. The basal conglomerate is normally less than $3 \mathrm{~m}$ thick, but it reaches its maximum exposed thickness of $3 \mathrm{~m}$ in a channel cut into the granodiorite $300 \mathrm{~m}$ east of the summit of Brady Butte $(1,220,750$ N., 378,900 E.). Here, well-rounded cobbles and boulders of leucocratic granophyre as much as $0.45 \mathrm{~m}$ in diameter are abundant and mixed with even larger subangular blocks derived from the underlying granodiorite (fig. 9).

North of Wolf Creek, the size of clasts and the thickness of the basal conglomerate decreases toward the southeast along the main trace of the unconformity. About $1.5 \mathrm{~km}$ northeast of Brady Butte $(1,223,300 \mathrm{~N}$., $381,400 \mathrm{E}$.), the contact is marked by a pebble conglomerate less than 1 to $1.2 \mathrm{~m}$ thick, that becomes interbedded with coarse-grained arkose toward the southeast. At several places along the southeastern segment of the unconformity, crossbedded arkose grades downward toward the granodiorite through 0.5 to $1 \mathrm{~m}$ of unbedded feldspathic rock thay may represent a Precambrian regolith developed in the Brady Butte Granodiorite. Pebble conglomerate occurs as lenses at many stratigraphic levels above the unconformity; the largest bodies are shown on the map (pl. 1).

More than half of the clasts in the conglomerate lenses are of finegrained alaskite or leucocratic granophyre that exhibits both porphyritic and seriate textures, containing albite and quartz grains 2 to 3

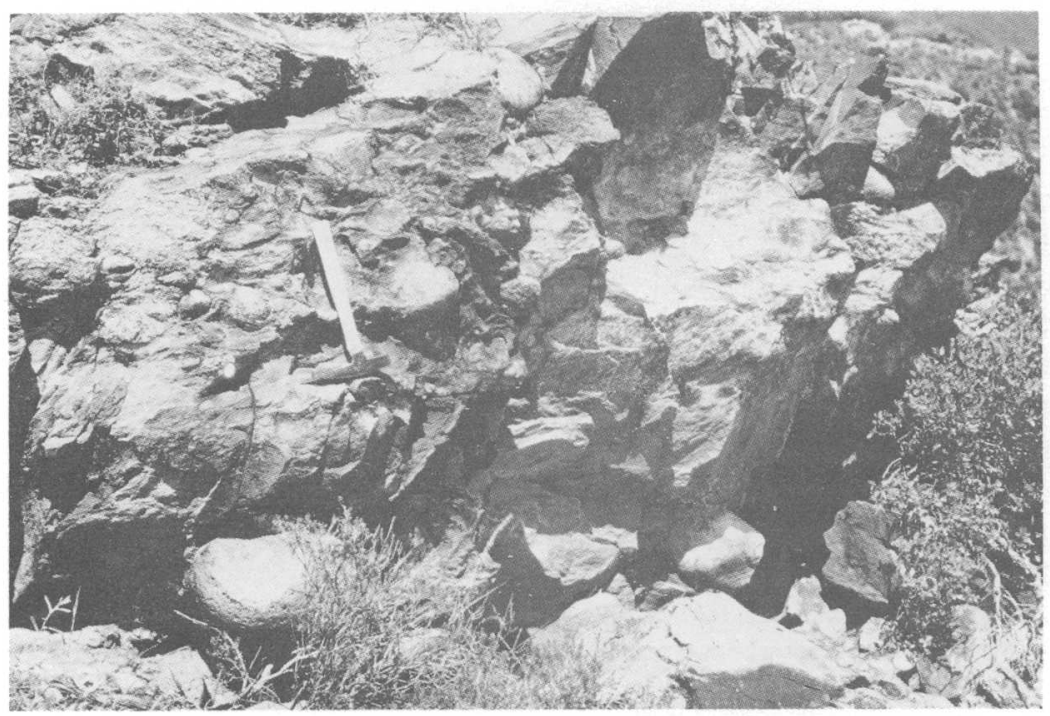

Figure 9.-Boulder conglomerate at base of the Texas Gulch Formation $300 \mathrm{~m}$ east of summit of Brady Butte. Note large well-rounded boulders of leucocratic granophyre. 
$\mathrm{mm}$ in length. Complex intergrowths of quartz, albite, and microcline distinguish all of the granophyres. Micrographic to spherulitic intergrowths of quartz and feldspar commonly form a matrix among plagioclase and quartz phenocrysts; X-ray data, extinction angles, and refractive indices indicate that the albite has an anorthite content of about 3 to 5 percent. Shreds of greenish-brown biotite and muscovite occur in many of the granophyre clasts.

Clasts of granular plutonic rocks are found only in the basal conglomerate. Weathering and erosional processes disintegrated the coarse-grained Brady Butte Granodiorite such that the granophyres persisted as coarse debris and were selectively concentrated in the conglomerates. Much of the arkosic matrix of the conglomerates and felspathic sandstones near the base of the Texas Gulch Formation was derived from disintegrated rocks similar to the granodiorite at Brady Butte. The source of the granophyric clasts is unknown, but the large sizes of some clasts in the basal conglomerate suggest a nearby source. Although granophyre consitutes more than 50 percent of the clasts in the conglomerate, the following rocks, given in order of abundance, have been identified: Jasper and dark chert, hematitic quartzite, white to light-gray quartzite, light-gray siltstone and argillite, light-gray shale or slate, porphyritic rhyolite, and dark-gray porphyry, with albite phenocrysts in a fine-grained biotite-sericite-quartz groundmass.

The matrix of the conglomerate is poorly sorted fine to very coarse grained feldspathic sandstone consisting of quartz, sodic plagioclase, and muscovite with lesser amounts of biotite and potassium feldspar. Relict detrital minerals include quartz, saussuritized plagioclase, microcline, albite, and micrographic quartz and feldspar. The relict grains are angular to subrounded. Minor accessory metamorphic minerals include tourmaline, apatite, sphene, and magnetite.

Relict bedding, cross stratification, and cut-and-fill structure are common in the arkosic sandstone interbedded with the basal conglomerate. Axial-plane foliation, $\mathrm{S}_{2}$, defined primarily by the orientation of muscovite is present universally. Where $\mathrm{S}_{2}$ is strongly developed in the finer textured conglomerates, the foliation is knotted as a result of flowage or wrapping of micaceous matrix around the rigid granules and pebbles. Foliation $\left(\mathrm{S}_{2}\right)$ of the conglomerates in the two elongate belts representing the east and west limbs of the major anticline is generally parallel to the relict bedding $\left(S_{1}\right)$ except in the hinge zones of minor folds. Parallelism between $S_{1}$ and $S_{2}$ is attained in the tightly folded basal conglomerate about $1.5 \mathrm{~km}$ north of Brady Butte. Foliation is nearly perpendicular to $S_{1}$ throughout most of the basal conglomerate and the overlying lens of pebble conglomerate along the slightly deformed segment of the unconformity northeast of Brady Butte (between 1,225,400 N., 379,000 E. and 1,222,000 N., 384,500 E.). 


\section{SLATE AND PHYLLITE}

Slate, phyllite, and rhyolitic tuff are widely interbedded with poorly sorted feldspathic and tuffaceous sandstone, the dominant rock of the Texas Gulch Formation in the Brady Butte area. These rocks are intermixed in the sandstone in zones or lenslike bodies that are generally too small to plot on the map (pl. 1).

The widespread distribution of slate and phyllite is indicated on the geologic map by the lineation arrows, which largely represent cleavage-bedding intersections in the fine-grained rocks. Gray slate is unusually abundant in a crudely lenticular area about $1,200 \mathrm{~m}$ long and as much as $300 \mathrm{~m}$ wide that extends northeastward from the intersection of two faults $1.6 \mathrm{~km}$ north-northeast of Brady Butte $(1,225,600 \mathrm{~N} ., 378,500 \mathrm{E}$.). This slaty lens is bounded on the southwest by the two faults and grades rapidly by intertonguing into feldspathic and tuffaceous sandstones about $300 \mathrm{~m}$ north of the quadrangle boundary.

In the eastern belt of the Texas Gulch Formation, slate and phyllite crop out in discontinuous zones that trend northeast-southwest approximately parallel to the general strike of the dominant foliation $\left(\mathrm{S}_{2}\right)$, major fault zones, and crossbedding delineated by the conglomerate zones (pl. 1). One phyllitic zone extends for about $1,800 \mathrm{~m}$ between 1,209,500 N., 380,400 E., and 1,203,000 N., 378,500 E., where it is expressed topographically by a line of small gullies and intervening saddles about $100 \mathrm{~m}$ or more east of the faulted margin of the Brady Butte Granodiorite. South of Turkey Creek, this zone of slate is exposed east of and stratigraphically above the conglomerate zone adjacent to the granodiorite. Phyllitic rocks occur north and south of this zone, parallel to the general trend of Bear Creek.

Throughout the broad crest of the major anticlinal structure north of the granodiorite core (pl. 2), relict bedding in the Texas Gulch Formation commonly has only a moderate dip. Along the Mayer-Goodwin road where it crosses Mule Canyon (1,225,800 N., 384,300 E.), gently dipping phyllite with pronounced bedding-plane foliation $\left(\mathrm{S}_{2}\right)$ is cut by strain cleavage $\left(\mathrm{S}_{3}\right)$, which dips westward parallel to the axial planes of small-scale asymmetric folds.

Much of the slate and higher grade phyllite was probably derived from shale or mudstone. Anderson and Creasey (1958, p. 29-30) published an analysis of typical purple slate within the Texas Gulch Formation in the Mingus Mountain quadrangle, probably a normal terrigenous sedimentary rock judged by the high $\mathrm{Al}_{2} \mathrm{O}_{3}$ content $(19.4$ percent), high ratio of $\mathrm{K}_{2} \mathrm{O}$ to $\mathrm{Na}_{2} \mathrm{O}$ (nearly 3:1), and overall similarity to the composite analysis of 51 samples of Paleozoic shale (Clarke, 1924, p. 552). 


\section{ARKOSIC SANDSTONE}

Fine-grained arkosic sandstone is abundant in the Texas Gulch Formation west of Brady Butte (between 1,223,500 N., 375,500 E. and $1,219,000 \mathrm{~N}$., $373,500 \mathrm{E}$.). This olive-gray to tan sandstone is poorly foliated,and bedding is only vaguely discernible in most outcrops; crossbedding is somewhat common near the base of the formation (fig. 10). At some localities, the dense fine granular texture of the sandstone imparts an almost hornfelsic character to the rock. Angular to subrounded relict plagioclase grains constitute about 50 percent of the rock. Relict grains of detrital gneiss range in diameter from 0.04 to 0.9 $\mathrm{mm}$; average diameter is about $0.15 \mathrm{~mm}$. Albite $\left(\mathrm{An}_{4-7}\right)$ constitutes at least 60 percent of the relict grains, quartz grains the remainder. The original sand:matrix ratio is probably about 2 .

West of Brady Butte, epidote is abundant in some beds, constituting about 20 percent of the rock. Fine granular epidote is concentrated in the matrix and commonly forms dense aggregates among the detrital plagioclase grains. The relict bedding seen in some outcrops is largely delineated by epidote. As calcite is only a minor constituent, the $\mathrm{CaO}$ released during saussuritization of the original detrital plagioclase and other calcium-bearing minerals presumably reacted with the argillaceous matrix to produce epidote.

In the northern exposures $(1,233,500$ N., 375,500 E.), the argillaceous matrix has recrystallized to a quartz-albite-epidote-muscovite-

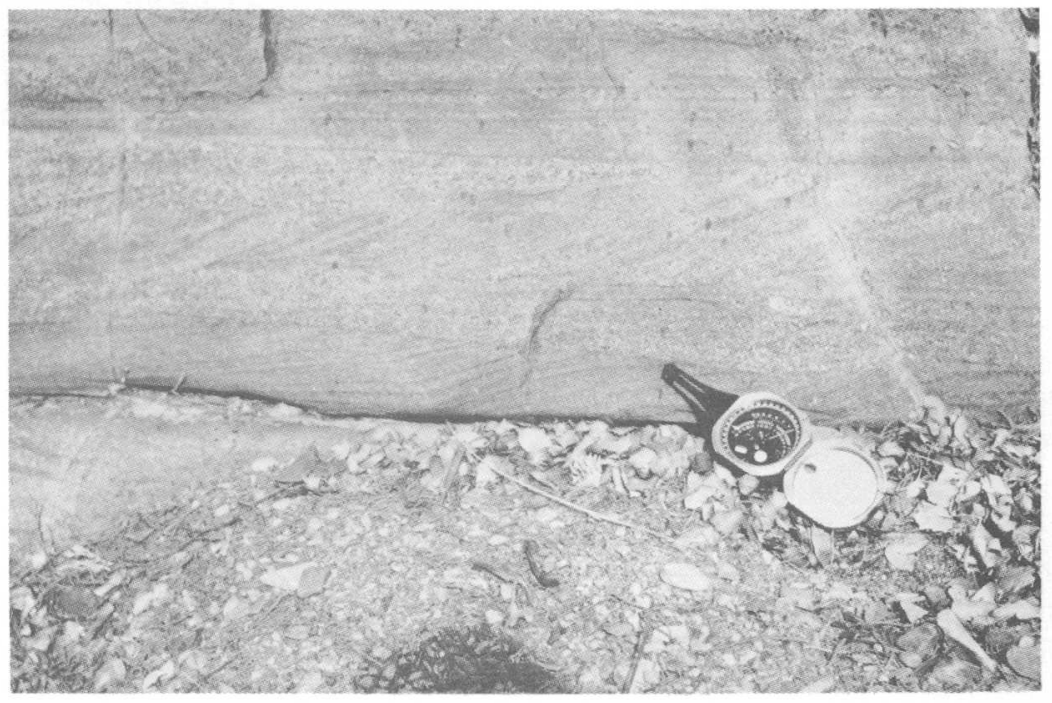

Figure 10.-Crossbedded arkosic sandstone in the Texas Gulch Formation, $1.2 \mathrm{~m}$ stratigraphically above the Brady Butte Granodiorite (1,222,800 N., 383,600 E.; pl.1). 
chlorite assemblage characteristic of the chlorite zone of the greenschist facies; yellow-brown biotite occurs locally. Southward, the metamorphic rank increases, and olive-green or brown biotite is a major mineral constituent that has crystallized at the expense of muscovite and chlorite. The transition between the chlorite and biotite zones within the arkosic rocks is near $1,224,000 \mathrm{~N}$.

Abundant quartzose fine- to medium-grained feldspathic wackes are characterized by a detrital quartz:feldspar ratio of at least $1: 1$. These light- to medium-gray sandy semischists are distinctly stratified; individual beds are less than $25 \mathrm{~m}$ to more than $0.3 \mathrm{~m}$ thick. Relict crossbedding is readily apparent at several localities, especially in the stratigraphic interval within $100 \mathrm{~m}$ of the unconformity northeast of Brady Butte $(1,224,700$ N., 380,300 E., and 1,224,500 N., 381,400 E.) and in the southern half of the western belt of Texas Gulch Formation $(1,217,200$ N., $372,200 \mathrm{E}$. and 1,208,700 N., 370,600 E.). Relict graded bedding was observed at one outcrop $(1,201,600 \mathrm{~N}$., $379,400 \mathrm{E}$.) where fine-grained micaceous sandstone is interbedded on a small scale with phyllitic sandstone. At this locality, grading in beds 6 to $75 \mathrm{~mm}$ thick is defined primarily by the gradual increase in muscovite upward from a sharply defined quartz-feldspathic layer. In this rock, $\mathrm{S}_{2}$ generally intersects $S_{1}$ at angles less than $10^{\circ}$.

Generally the more quartzose wackes are better sorted and relict detrital grains more rounded than the feldspathic epidote-rich wackes west of Brady Butte. Relict detrital grains are quartz, albite, oligoclase, microcline, and micrographic intergrowths of quartz and feldspar. Lithic grains are quartzite or metachert and rhyolitic granophyre. The matrix has recrystallized to quartz, sodic plagioclase, and muscovite, with or without chlorite, biotite, and epidote. Biotite is generally olive green or brown and generally darker in the southern half of the Brady Butte area. All of the Texas Gulch Formation in this area has undergone regional metamorphism equivalent to the quartzalbite-epidote-biotite subfacies of the greenschist facies. Epidote is widespread in the wackes; at some localities, it may constitute nearly 10 percent of the rocks $(1,207,500 \mathrm{~N}$., $380,000 \mathrm{E}$.). In the eastern belt of the Texas Gulch Formation, the plagioclase is albite $\left(\mathrm{An}_{4-7}\right)$ north of $1,215,000 \mathrm{~N}$., oligoclase $\left(\mathrm{An}_{17}\right)$ south of $1,210,000 \mathrm{~N}$. (pl. 1). The hightemperature boundary of the greenschist facies (Turner and Verhoogen, 1960) must lie within this $1,525 \mathrm{~m}$ interval (pl. 1). North of Battle Flat, the wackes of the western belt are characterized by albite coexisting with epidote and are therefore included in the greenschist facies (pl. 1).

Coarse-grained arkose and feldspathic sandstone are abundant in the basal $100 \mathrm{~m}$ above the Brady Butte Granodiorite and occur as 
interbeds with the conglomerates of both the eastern and western belts. Subangular to rounded felsitic and granophyric granules as much as $\mathbf{4 m m}$ in diameter are locally abundant. These sandstones are poorly sorted and the recrystallized matrix, largely muscovite, commonly constitutes about 20 percent of the rocks.

\section{TUFFACEOUS SANDSTONE}

The tuffaceous sandstone has a mixed origin, evident in epiclastic debris, pyroclastic ejecta, and nonvolcanic detritus. Bedded tuffaceous sandstone, in part derived by reworking and subaqueous deposition of rhyolitic pyroclastic ejecta, probably constitutes the bulk of the fine- to coarse-grained volcaniclastic sandstone in the Brady Butte area. The light-gray poorly sorted tuffaceous sandstones and rhyolitic tuffs are very fine to coarse grained, containing some lapilli tuff or tuffaceous pebble conglomerate. Most of the tuffaceous sandstone is medium grained; grains are rounded and range in diameter from 0.10 to $1 \mathrm{~mm}$. Relict bedding is generally apparent, and individual beds range from $25 \mathrm{~mm}$ to more than $1 \mathrm{~m}$ thick. Crossbedding and channeling are found locally in feldspathic wackes, interbedded with rhyolitic tuffs.

White discoidal or platy wisps of sericite occur in the volcaniclastic rocks at several localities $(1,222,000 \mathrm{~N}$., $378,300 \mathrm{E} . ; 1,223,500 \mathrm{~N}$., $374,200 \mathrm{E}$.), and these sericitic clasts resemble collapsed pumice lapilli in unmetamorphosed pyroclastic rocks. These lapilli have length: thickness ratios greater than 10 and commonly are constricted or bent between lithic or crystal clasts.

Volcanic detritus that may be both epiclastic and pyroclastic is represented by collapsed pumice lapilli; microcrystalline devitrified glass or rhyolite, consisting of quartz, alkali feldspar, and sericite, with or without quartz and albite phenocrysts or microlites; and broken quartz phenocrysts with partial crystal faces, embayed in part by partial resorption. Nonvolcanic grains include graphic or micrographic intergrowths of quartz and alkali feldspar, granophyric lithic grains, and subordinate quartz aggregates, probably quartzite and chert.

Muscovite or sericite, quartz, and albite are the major metamorphic constituents of the tuffaceous rocks, but biotite may substitute for most of the muscovite in some tuffs and is commonly an accessory mineral. Chlorite, magnetite, clinozoisite, and epidote are metamorphic accessories. 


\section{YOUNGER PLUTONIC ROCKS}

\section{GRAZY BASIN QUARTZ MONZONITE}

The Crazy Basin Quartz Monzonite is well exposed in the southeastern corner of the Brady Butte area, extending for less than $1 \frac{1 / 2}{\mathrm{~km}}$ eastward into the Cordes area (Anderson, 1972). Southward this quartz monzonite forms a triangle-shaped batholith exposed in an area of approximately $260 \mathrm{~km}^{2}$ in the rugged southern part of the Bradshaw Mountains. The concordance of the granitic contacts with foliation and stratification in the adjacent schists was first noted by Jaggar and Palache $(1905$, p. 7$)$, who cited this relation as evidence of forceful intrusion: "*** in the case of the large southern stock of the Bradshaw Mountains in the divergence of the schist banding east and west about the northern end of the stock (along Crazy Basin Creek) suggests the splitting apart of the isoclinals by invasion of the granitic magma." The present study has confirmed and more precisely delineated these structural relations, and the conclusion is reached that granitoid magma made room for itself by mechanically displacing large volumes of the regionally metamorphosed schists of the Yavapai Series. The displacement of the country rock, at the present level of exposure, has a large horizontal component with an unknown and possible vertical component, especially evident adjacent to the northward-plunging plutonic nose constituting the quartz monzonite near Crazy Basin Creek.

Light-gray medium-grained porphyritic muscovite biotite quartz monzonite is the dominant rock in the interior of the pluton near Blancho Spring and southward along the road to Crown King. Nonporphyritic varieties are widely distributed near the intrusive contact and especially near the southeastern corner of the quadrangle. Textures vary from hypidiomorphic-granular to xenomorphic-granular in local areas of aplite and masses and dikes of granite pegmatite. Along moderate- to steep-dipping joints present throughout the pluton, weathering accompanied by exfoliation along these main sets of joints has produced massive, rounded or bouldery, light-yellowish-gray rock that crops out in linear pattern. The most conspicuous joint set strikes within $10^{\circ}$ of east-west, and the joints of this set generally dip $75^{\circ}-90^{\circ}$ S., except near the contact along Crazy Basin Creek, where they dip $55^{\circ}-65^{\circ} \mathrm{N}$., approximately parallel to the dip of the intrusive contact and foliation in the adjacent schist. Prominent sets of moderately to steeply dipping joints strike northwest and north to northeast. Thin 
pegmatite dikes commonly occupy or are parallel to joints in the quartz monzonite.

Microcline-microperthite occurs as subhedral megacrysts and anhedral grains in the medium-grained groundmass and nonporphyritic quartz monzonite. The megacrysts are generally nearly equant or form stubby tablets, and range in maximum size from 8 to 15 $\mathrm{mm}$. In an area southeast of Blancho Spring (1,183,000 N., 387,500 E.), distinct microcline tablets arranged in a subparallel pattern define a foliation that is parallel to the northeast-trending segment of the intrusive contact northeast of Blancho Spring. Orientation of these tablets probably reflects a primary foliation resulting from differential flowage in the quartz monzonite magma. Petrographic studies reveal that the microcline phenocrysts are extensively replaced by myrmekite, tending to make them more irregular in outline. Typical gridtwinning is sharply defined in all the microcline, which contains minute exsolution lamellae of albite.

The composition of the plagioclase ranges from albite $\left(\mathrm{An}_{4}\right)$ to calcic oligoclase $\left(\mathrm{An}_{29}\right)$ that coexists with microcline. The potassium feldspar is equal to or greater than plagioclase in abundance. Oligoclase with an anorthite content of 12 to 16 percent is the dominant plagioclase, commonly mantled by a narrow, sharply bounded zone of albite $\left(\mathrm{An}_{4-6}\right)$. Subhedral oligoclase commonly grades inward to more calcic cores $\left(\mathrm{An}_{29}\right)$ and locally contains granules of clinozoisite. Polysynthetic twinning is typical of the albite-oligoclase crystals but is lacking in the abundant myrmekitic plagioclase, which forms lobate bodies extending from lamellar-twinned oligoclase into adjacent microcline.

Quartz constitutes about 30 to 35 percent of the quartz monzonite, forming large anhedral grains exhibiting planar or only slightly undulous extinction, minute wormlike inclusions in myrmekite, and blebs in microcline. The coarse anhedral grains are generally linked together, forming irregular patches a centimeter or more in length. Brown biotite and muscovite are present in all rocks examined in thin section. These micas occur in about equal proportions, but either may predominate locally. Ragged patches of coarse muscovite, as well as flakes of muscovite included in myrmekitic plagioclase, may represent crystallization of muscovite related to potassium redistribution during the development of myrmekite. Two chemical analyses are given in table 2 (nos. 5,6 ).

\section{PEGMATITIC ROCKS}

Quartz-microcline-muscovite pegmatites are numerous and widely distributed in the Crazy Basin Quartz Monzonite and in sedimentary 
rocks of the Spud Mountain Volcanics surrounding this pluton. The mineralogy of these granite pegmatites is simple. Microcline-perthite is generally the most abundant mineral, followed by quartz and muscovite in that order of abundance. Some black tourmaline is usually present, and fine black needles of tourmaline commonly impregnate adjacent schistose rocks in zones a few centimeters in width. One pegmatite dike in the Crazy Basin pluton is complexly intermixed with aplite containing subradiating masses of black tourmaline with some 25 -mm-long prisms. Biotite is an accessory in a few pegmatites, but books of muscovite, as much as $125 \mathrm{~mm}$ across are more than $25 \mathrm{~mm}$ thick.

At a few localities in the staurolite- and andalusite-bearing schist of the inner part of the contact aureole (as at 1,189,500 N., 388,500 E.), coarsely prismatic masses of pink andalusite occur in small podlike bodies of quartz-microcline-muscovite pegmatite containing accessory tourmaline and biotite. Scheelite occurs sparsely in small pockets in some of the pegmatite dikes east of the De Soto mine and at several small prospects in silicified and epidote- and tourmaline-bearing schist and pegmatite about $6 \mathrm{~km}$ north of Crazy Basin Creek $(1,196,200$ N., 397,000 E.; Dale, 1961, p. 25-26).

Several pegmatite dikes near Crazy Basin Creek crosscut the Crazy Basin Quartz Monzonite and extend into metamorphosed sedimentary rocks of the Spud Mountain Volcanics approximately parallel to the foliation in the innermost part of the plutonic aureole. Although these dikes clearly postdate the intrusive movement of the quartz monzonite, their close association and chemical compatibility with the pluton indicates that they are genetically related to the Crazy Basin Quartz Monzonite.

\section{MINOR INTRUSIVE ROCKS}

\section{MAFIC ROCKS}

Gabbroic rocks are widely exposed throughout much of the Yavapai Series north and northeast of the Brady Butte area (Anderson and Creasey, 1958; Anderson and Blacet, 1972a; Anderson, 1972), where these rocks may represent more than one period of mafic intrusive activity. Three small bodies of gabbro intrude the Iron King Volcanics in the northeast quadrant of the Brady Butte area, and although they may be genetically related to the Iron King Volcanics, the absence of foliation in the metamorphosed gabbro suggests that they postdate the intense deformation of the Big Bug Group but predate the superimposed amphibolite-facies metamorphism associated with the Crazy 
Basin Quartz Monzonite. The gabbro masses that intruded the Iron King Volcanics are medium grained and equigranular; these rocks appear somewhat porphyritic owing to light-olive-gray, subhedral to euhedral plagioclase crystals suspended in a dark-greenish-gray base of metamorphic amphibole.

Diorite is exposed only in three dikes north of Battle Flat. It is greenish gray and the texture hypidiomorphic-granular; saussuritized plagioclase clearly predominates over dark minerals.

Three pluglike bodies of metamorphosed hornblendite are intrusive into the Spud Mountain Volcanics southwest of Battle Flat; a similar dike crops out along the fault contact between the Brady Butte Granodiorite and Texas Gulch Formation, $3.2 \mathrm{~km}$ southeast of Battle Flat $(1,192,000$ N., 373,000 E.). This mafic dike postdates the major movement of the localizing fault and predates the amphibolite-facies metamorphism that affected it and the Brady Butte Granodiorite and Texas Gulch Formation.

\section{SILICIC ROCKS}

A large concordant intrusive mass of albitic porphyry was injected into the western belt of Texas Gulch Formation for about $3 \mathrm{~km}$ northward from the east margin of Battle Flat. Foliation in this porphyritic body is approximately parallel to $S_{2}$ foliation in the host rocks; its cataclastic texture is revealed by rounded, augenlike phenocrysts of albite set in a fine-grained and somewhat foliated matrix. Small rounded quartz phenocrysts occur sparsely in some outcrops. The porphyry weathers to light yellowish or pinkish gray; in places, it has weathered to form a mantle of sandy soil around scattered blocky outcrops. Black coatings of tourmaline form the matrix of a narrow breccia zone in the porphyry.

Where cataclasis has been slight, coarse-grained and complexly twinned albite occurs as euhedral equant or thickly tabular phenocrysts 3 to $6 \mathrm{~mm}$ in size embedded in a fine-grained groundmass of subhedral albite and interstitial quartz. Granules of epidote, calcite, and sericite are evenly scattered throughout the phenocrysts, probably indicating an original calcic composition. Irregular aggregates of olivegreen biotite and spongy anhedral crystals of muscovite are about equally abundant. Minor and accessory minerals are calcite, epidote, magnetite, and apatite.

All of the medium-grained leucocratic siliceous rocks that form small lensoid intrusive bodies in the western part of the quadrangle are referred to as alaskite (pl. 1). These white to pale-yellowish-gray rocks include a variety of textural types ranging from micropegmatite and 
saccharoidal aplite to hypidiomorphic-granular alaskite. Albite is the dominant feldspar, and irregular patches of albite cut coarse microcline, abundant myrmekite, and chessboard twinning in albite. Granules of clinozoisite and sericite in plagioclase indicate that albitization of earlier microcline and plagioclase has been widespsread. Crushed anhedral grains of quartz and fine granular quartz occur as parallel lenticles and stringers that constitute about 30 to 40 percent of the rocks. Muscovite exceeds biotite in abundance; together micas make up less than 10 percent of the rock. The cataclastic alaskite are concentrated near the west margin of the Brady Butte area and increase in number westward toward the Crooks Canyon Granodiorite, 3 to $5 \mathrm{~km}$ west of the area.

\section{STRUCTURE OF THE PROTEROZOIC ROCKS}

\section{PRINCIPAL FEATURES}

Proterozoic structures in the Brady Butte area consist of faults, isoclinal folds, axial plane foliation, and lineations. Steeply dipping north- to northeast-striking faults divide the Proterozoic rocks into three major structural blocks: (1) a western block of northwest-dipping Spud Mountain Volcanics; (2) a central narrow anticlinal block of Brady Butte Granodiorite and the unconformably overlying Texas Gulch Formation; and (3) an eastern predominantly northwest-dipping sequence of Spud Mountain sedimentary rocks and conformably overlying Iron King Volcanics. The Shylock fault, a major regional fault, cuts the eastern mass of Spud Mountain Volcanics (pl. 2).

The structural setting of the Brady Butte area within the Proterozoic terrane of the northern Bradshaw Mountains as compiled on plate 2 combines the generalized geologic and structural interpretations of Anderson and Creasey (1958), Blacet (1966), Anderson (1967, 1972), and Anderson and Blacet (1972a).

The major structures in the Brady Butte area originated during two or more periods of deformation. Two periods, the later at least sufficiently intense to produce isoclinal folds and foliation, are revealed by the relation of the Brady Butte Granodiorite to the Spud Mountain Volcanics and the Texas Gulch Formation. The extent to which the Spud Mountain Volcanics and Iron King Volcanics were deformed prior to the deposition of the Texas Gulch Formation cannot be documented. However, plutonic intrusions commonly mark the waning stages of strong deformation, and whatever deformation was associated with intrusion of the Brady Butte Granodiorite preceded the Texas Gulch Formation. The Brady Butte Granodiorite intruded the Spud Moun- 
tain Volcanics but is unconformably overlain by the Texas Gulch Formation. The bulk of the Brady Butte was a medium- to coarse-grained hypidiomorphic-granular plutonic rock that must have been emplaced at depths of several kilometers at least. Following intrusion of the Brady Butte Granodiorite, uplift and erosion exposed the granodiorite, and the Texas Gulch Formation was deposited on its eroded surface. Subsequent subsidence and burial to depths below where brittle fracture occurs was accompanied by intense compressional deformation manifest by isoclinal folds, axial plane foliation, and gently plunging B-lineations. This deformation affected the Iron King and Spud Mountain Volcanics as well as the Texas Gulch Formation and the Brady Butte Granodiorite. The general parallelism of fold axes and foliation in the Spud Mountain Volcanics, Iron King Volcanics, and Texas Gulch Formation indicates that all were subject to a common period of strong amphibolite facies regional metamorphism, although they are now generally bounded by regionally extensive, north- to north-northeaststriking faults.

The age of the faults that separate the three formations into the western, central, and eastern blocks is problematical. The spatial relations of the formations show that the Texas Gulch Formation is faulted down against the Spud Mountain Volcanics on the west and down against the Iron King Volcanics on the east. As these relations suggest crustal extension, the bounding faults may have formed during deformation separate from the events that produced the isoclinal folds and foliation. Yet a special case could produce the present relations during compressional deformation.

If the displacement on the faults bounding the Texas Gulch Formation was nearly horizontal and if the sense of lateral displacement was the same as the plunge of the folds, then the Texas Gulch Formation could have moved against older formations without any dip-slip component. These constraints require the movement on the fault bounding the Texas Gulch Formation on the west to be right lateral and that on the east to be left lateral. Both of these senses of displacement are compatible with an east-west crustal shortening if they are conjugate shears. It is clear, however, that these faults did not form during the period of deformation that produced the isoclinal folds and axial-plane foliation. The faults transect fold axes, commonly contain fault slivers of adjacent formations, and deform the regional foliation to a nearly vertical attitude. Moreover, retrograde greenschist metamorphism accompanied faulting in the amphibolite-grade Iron King Volcanics along the two northeast-trending faults that bound the central block on the east. The Shylock fault zone shows similar retrograde metamorphism and probably formed during the same deformational period. 
If the theory of extensive strike-slip displacement is valid, the fault along the west side of the central block must extend southward for a considerable distance beyond where the fault leaves the porphyritic facies of the Brady Butte Granodiorite. The extent of this fault has not been reexamined since the final stratigraphic order of the Precambrian rocks was established through uranium-lead isotopic ages on zircons. This fault may extend much farther south than the original mapping indicated.

\section{WESTERN BLOCK}

The gross distribution of the lithologic units in the Spud Mountain Volcanics demonstrates a northeastward- and southwestward-plunging, isoclinal overturned anticline with a saddle-shaped depression south of Big Bug Mesa (pl. 2). Foliation $\left(\mathrm{S}_{2}\right)$ retains a consistent northeast strike and steep northwest dip throughout the western block, where it closely parallels $S_{1}$ and the axial plane of the overturned anticline. Pumice lapilli in tuff and breccia commonly exhibit extreme compression perpendicular to $S_{2}$ and a slight to moderate elongation nearly parallel to the dip of $S_{2}$.

Mineral streaking, approximately down the dip of $\mathrm{S}_{2}$, is the dominant lineation in the western block (domain I, pl. 2) and in that part of the eastern block containing the amygdaloidal and pillow basalt unit of the Iron King Volcanics, (domain IV, pl. 2); this lineation is absent in the central block.

\section{CENTRAL BLOCK}

Large-scale faulting has complicated the structure of the central block, but its overall character is that of an anticline developed in the Texas Gulch Formation and cored by the gneissic Brady Butte Granodiorite. The displaced eastern limb is overturned south of $1,217,000 \mathrm{~N}$. (pl. 1 , secs. $B-B^{\prime}, C-C^{\prime}$, and $D-D^{\prime}$ ). In the vicinity of Brady Butte, the anticline plunges north-northeastward at about $20^{\circ}$ (pl. 2). Axes of minor folds (pl. 1) and the intersections of bedding and cleavage (pl. 1) mark B-lineations that are widely developed in the Texas Gulch Formation; these lineations plunge approximately parallel to the main anticlinal axis in the western limb and in the broad crestal region north and northeast of Brady Butte (domain II, pl. 2). In the fault-offset eastern limb (domain III, pl. 2), the minor fold axes and cleavagebedding intersections generally plunge south-southwestward at 
angles less than $20^{\circ}$; south of $1,205,000 \mathrm{~N}$., the plunge is locally reversed such that it is subparallel to the major anticlinal axis. This reversal may be another indication of subsequent low-amplitude folding parallel to northwest axes, or it may reflect strike slip sufficient to juxtapose domains of different plunge direction.

\section{EASTERN BLOCK}

The eastern block contains at least $3,000 \mathrm{~m}$ of volcanic and sedimentary rocks of the Spud Mountain Volcanics and overlying Iron King Volcanics, which dip steeply to the northwest. Isoclinal and tight folding within this block is demonstrated by the deformed contact at the base of the Iron King Volcanics, volcanic breccia and conglomerate of the Iron King folded into the sedimentary unit of the Spud Mountain Volcanics (pls. 1, 2); and a zone of eastward-facing overturned pillow basalt $(1,213,800 \mathrm{~N}$., $388,800 \mathrm{E}$.) that nearly parallels the west-facing contact at the top of the Spud Mountain Volcanics. Relict pillow structures, though commonly recognizable, are rarely preserved to the extent that their stratigraphic tops can be determined. The regional paucity of reliable top determinations is illustrated graphically on the structure map, which shows most of the areas where relict structures clearly indicate the local stratigraphic succession. Relict bedding and the gross stratigraphy are parallel, or nearly so, to a well-developed foliation $\left(\mathrm{S}_{2}\right)$ that bears an axial-plane relation to the major folds (pl. 2).

In contrast to the amygdaloidal and pillow basalt of the Iron King Volcanics, in which $\mathrm{S}_{2}$ and mineral streaking maintain a consistent northwest dip similar to that prevailing in the western block, the quartz-feldspathic and pelitic schists of the sedimentary unit of the Spud Mountain are characterized by intense deformation of $S_{1}$ and $S_{2}$ with the common development of microcrenulated $S_{2}$ and related $S_{3}$ strain-slip or fracture cleavage. Although deformation of $S_{2}$ is by no means restricted to the Spud Mountain's sedimentary unit surrounding the quartz monzonite, nowhere in the Brady Butte area is this later period of deformation so evident. The intensity of this superimposed deformation and the orientational consistency of its structural elements increases markedly toward the quartz monzonite contact, indicating that the intrusion of this large pluton is related to the second deformation.

Mapped intrusive relations, associated pegmatite dikes, and the concentric metamorphic zonation (pl. 2) prove that the undeformed Crazy Basin Quartz Monzonite is intrusive into sedimentary rocks of the Spud Mountain Volcanics. It might be argued that after its intrusion, this large plutonic mass acted as a buttress against which the 
adjacent schists were compressed during a deformational event unrelated to the granitic intrusion. This hypothesis is untenable because of the undeformed character of the plutons and the general occurrence of crenulated muscovite schist adjacent to the quartz monzonite that has been coarsely recrystallized after its last deformation. The introduction of quartz and tourmaline in substantial quantities during various stages of this secondary deformation also suggests a temporal relation between the deformation and granitic magmatism.

Relict bedding $\left(\mathrm{S}_{1}\right)$ and laminar structure that is probably related to bedding occur widely throughout the micaceous schists of the Spud Mountain's sedimentary unit. $S_{2}$ parallels $S_{1}$, or transects it at low angles, producing parallel streaks on $\mathrm{S}_{2}$ (indicated as mineral streaking on pl. 1), but this lineation is almost certainly equivalent to cleavage-bedding intersection (pl. 1). A wide scattering of lineation orientations characterizes the sedimentary unit in the outer part of the contact aureole (domain V, pl. 2), and this region seems to represent a transition from the normal north-northeast to northeast structural trends through domain IV to the strongly deflected structural elements near the quartz monzonite. The stereographic projection for domain VI (pl. 2) reflects a broad arching of gently plunging B-lineations across a north- or north-northwest-trending axial zone, which may overlie the crest of a north- or north-northwest-plunging nose of quartz monzonite. $S_{1}$ and $S_{2}$ are crosscut by an $S_{3}$ strain-slip or fracture cleavage parallel to the axial planes of small-scale folds (fig. 4). The intersections of $\mathrm{S}_{2}$ and $\mathrm{S}_{3}$ form conspicuous crenulation on $\mathrm{S}_{2}$ (pls. 1,2 ). The generalized structure map of the foliated rocks north of the Crazy Basin Quartz Monzonite, figure 11, illustrates the general northward plunge of $\mathrm{S}_{2}-\mathrm{S}_{3}$ intersections, and the relation of this lineation to $\mathrm{S}_{2}$, which is deflected into parallelism with the northward plunging, arcuate contact of the pluton.

The structural geometry of the contact aureole indicates strong compression of the sedimentary unit normal to the contact, possibly the result of balloon-like magmatic inflation of the quartz monzonite during its intrusion. After $S_{1}$ and $S_{2}$ were rotated nearly parallel to the intrusive contact, the pluton apparently continued to expand and stress was relieved by movement along a new set of slip planes $\left(\mathrm{S}_{3}\right)$ that probably developed at about $30^{\circ}$ to the principal compressive stress $\left(\sigma_{1}\right.$, assumed to have been perpendicular to the intrusive contact). The sterographic projection (fig. 11) demonstrates that northeast-dipping slip planes $\left(\mathrm{S}_{3}\right)$ oriented at about $30^{\circ}$ to $\sigma_{1}$ could have produced the crenulations on $\mathrm{S}_{2}$ observed in a representative domain adjacent to the contact. Small-scale folds, developed largely by slip parallel to their axial planes, commonly plunge steeply northwest especially in domain $\mathrm{V}$ (pl. 2), constituting evidence of nonaffine deformation by movement 


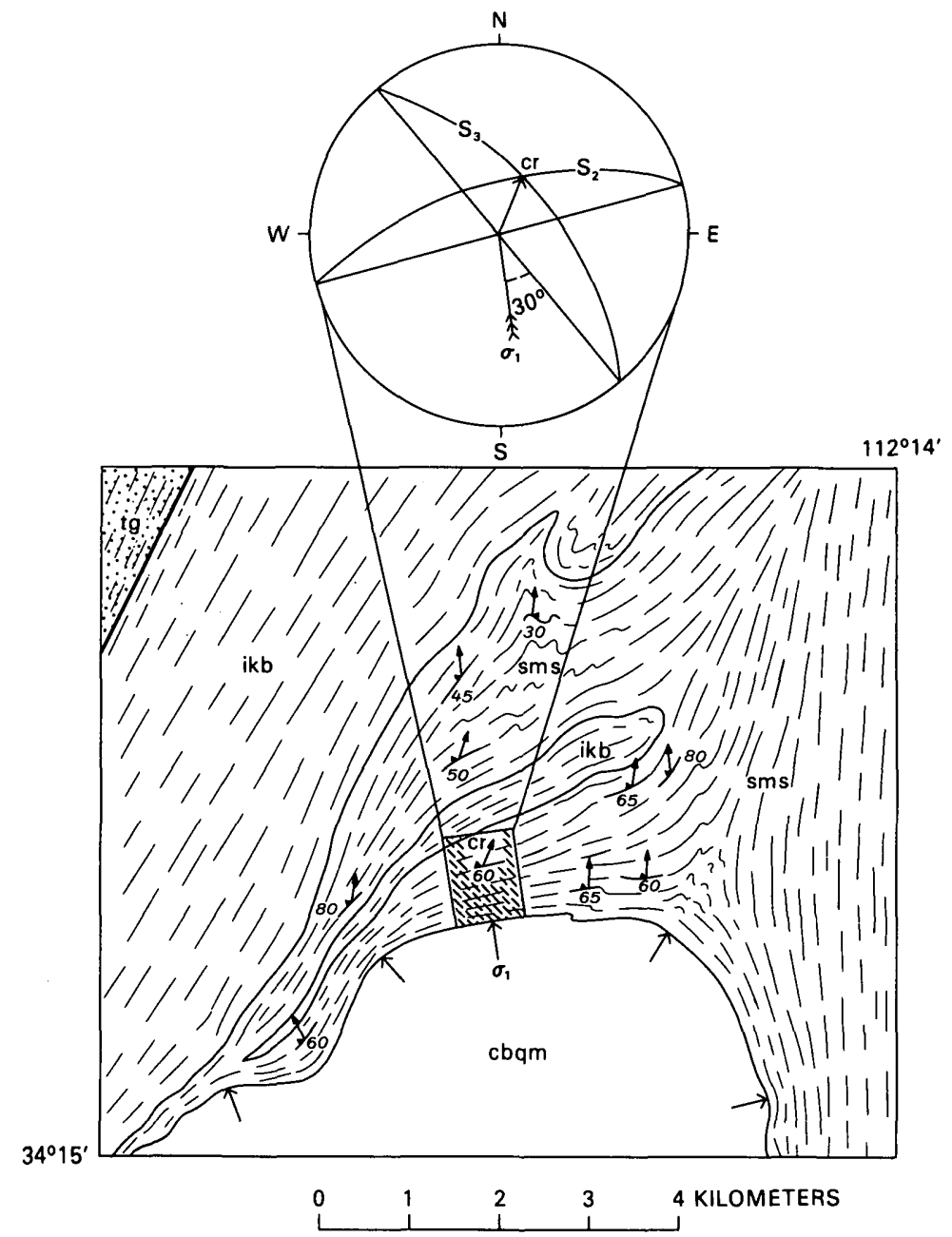

EXPLANATION

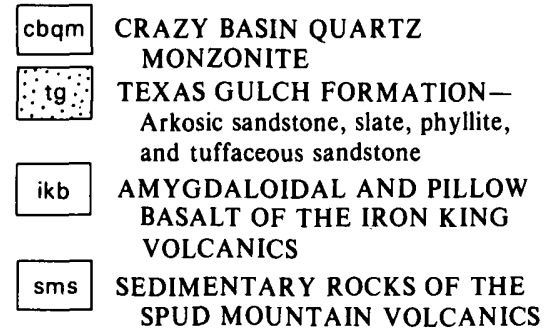

$\begin{array}{cl}\text { _- Contact-Approximately located } \\ \text { Fault-Approximately located } \\ \text { cr } & \begin{array}{c}\text { Strike and dip of foliation-Arrow } \\ \text { indicates bearing and plunge of } \\ \text { lineation } \\ \text { Crenulated foliation }-\mathrm{S}_{2}-\mathrm{S}_{3} \text { inter- } \\ \text { section }\end{array} \\ \mathrm{S}_{2} & \text { Foliation } \\ \mathrm{S}_{3} & \text { Strain-slip cleavage } \\ \sigma_{1} & \text { Direction of principal stress }\end{array}$

FIGURE 11.-Generalized structure map of contact aureole, illustrating deflection of $\mathrm{S}_{2}$ (long dashes) around the Crazy Basin Quart Monzonite and general northward plunge of $S_{2}-S_{3}$ intersections (arrows). Stereographic projection demonstrates that $\mathrm{S}_{3}$ slip planes or kink bands (short dashes) that intersect $\sigma_{1}$ at $30^{\circ}$ could produce $S_{2}$ $\mathrm{S}_{3}$ lineation observed in a representative domain (outlined) adjacent to intrusive contact. 
along northwest-striking $S_{3}$ slip planes. Although $\sigma_{1}$ was oriented generally north to northwest in the aureole within the Brady Butte area, the movement picture was no doubt complicated by differential rotation and slip along $S_{1}, S_{2}$, and $S_{3}$, and possibly by the local development of a set of slip planes opposing $S_{3}$. The complex structure of the sedimentary unit of the Spud Mountain Volcanics is the combined result of movement along, and (or) flexure of, at least three S-surfaces in response to a heterogeneous stress field in which $\sigma_{1}$ radiated outward from the quartz monzonite contact.

\section{CHAPARRAL AND SHYLOCK FAULTS}

The Chaparral fault, which separates the Green Gulch Volcanics on the north from the Spud Mountain Volcanics on the south, is a northeast-trending strike-slip fault (pl. 2). It trends more easterly than either the faults bounding the Texas Gulch Formation or the Shylock fault. Unfortunately, the points of fault intersections are beneath the gravels of Lonesome Valley, which is north of the area represented by pl. 2. The Shylock fault is clearly not offset by the Chaparral, but the relations between the Chaparral and the faults bounding the Texas Gulch Formation are unknown. The sense of movement on the Chaparral is compatible with an east-west crustal shortening. Since it cuts and deforms northward trending contacts and foliation in the Green Gulch Volcanics, it is younger than some foliation but could be a latestage manifestation of a more or less continuous period of east-west compression.

The Shylock fault is a north-trending right-lateral wrench fault that has been mapped for a distance of $48 \mathrm{~km}$ (Anderson, 1967). In the Mingus Mountain quadrangle, northeast of the Brady Butte area, the fault is covered by unbroken Paleozoic sedimentary rocks, indicating no Phanerozoic displacement. The sense of movement on the Shylock and Chaparral is the same; they cannot be members of a conjugate fault system even though they are separated in strike direction by about $45^{\circ}$.

\section{METAMORPHIC ZONATION}

Many of the volcanic and sedimentary rocks represented on the map showing the structure and metamorphism, plate 2, contain an albitechlorite-epidote assemblage (isograd I). Isograds defined by the first occurrence of blue-green hornblende (isograd II), plagioclase $\mathrm{An}_{15}$ (isograd III), and staurolite and andalusite (isograd IV) are drawn on the basis of petrographic examination of approximately 250 thin sections.

The distribution of the upper greenschist and amphibolite facies assemblages reflected by the isograds is interpreted as resulting from 
partial metamorphic reequilibration of the rocks in response to temperature gradients superimposed by the regionally metamorphosed greenschists of the Big Bug Group. These thermal, and to some extent, chemical gradients were imposed during the intrusion and cooling of the large granitic plutons exposed in the southwestern and southeastern parts of the quadrangle in the southern Bradshaw Mountains and in the Crooks Canyon Granodiorite to the west (pl. 2). The temperature gradient associated with the porphyritic facies of the Brady Butte Granodiorite appears to have affected the Spud Mountain Volcanics in the western block before the end of deformation, whereas static crystallization, or annealing, was prevalent after pervasive deformation had ceased in the southeastern part of the quadrangle, particularly in rocks adjacent to the Crazy Basin pluton.

\section{LATE CRETACEOUS OR EARLY TERTIARY ROCKS}

Rocks of Late Cretaceous or early Tertiary age in the Brady Butte area are entirely igneous in origin, and are similar in some respect to granodiorite and associated granodiorite porphyry that intrudes the Precambrian terrane west of Crown King, $14.5 \mathrm{~km}$ south of Pine Flat (Lindgren, 1926, p. 21-22). Similar discordant stocks of fine- to medium-grained granodiorite are exposed to the north in the $\mathrm{NE}^{1 / 4}$ Mount Union quadrangle; potassium-argon dates indicate that the stock at Walker is 64 m.y. old, the one along Big Bug Creek 70 m.y. old (Anderson and Blacet, 1972a, p. 51).

\section{QUARTZ LATITE PORPHYRY}

A small stock that underlies Pine Flat in the northwest corner of the map area (pl. 1) grades from quartz latite porphyry in eastern exposures to granodiorite porphyry in western.

Where argillization, silicification, and other types of hydrothermal alteration have been slight, thin sections of the quartz latite porphyry reveal euhedral, oscillatory zoned, and complexly twinned oligoclase phenocrysts set in a fine-grained to aphanitic groundmass of anhedral quartz and K-feldspar. Extremely rounded and embayed quartz phenocrysts and partially argillized or chloritized biotite crystals are conspicuous. Euhedral prisms of chloritized hornblende were observed in some thin sections. Stubby prisms of apatite, coarse granular sphene, and magnetite are ubiquitous accessory minerals. Miarolitic cavities filled with carbonate and quartz crystals are not uncommon. Intense alteration is accompanied by bleaching of the fresh light-gray 
speckled rock to dull white or cream color, commonly stained with hydrous iron oxides produced by oxidation of disseminated pyrite and chalcopyrite.

Jaggar and Palache (1905, p. 9) first noted the close association between the Cretaceous or early Tertiary granodiorite, including its fine-grained porphyritic relatives, and the postdeformational metallic vein deposits. Disseminated pyrite, chalcopyrite, and minor molybdenite occur in brecciated and intensely altered pipelike bodies cutting the latite porphyry at Pine Flat as well as in the granodiorite in the Crown King quadrangle. Intense alteration is characteristic of all the silicic porphyries in the Brady Butte area.

\section{RHYOLITE PORPHYRY}

Rhyolite porphyry occurs as dikes that extend from the northeastern part of the Brady Butte area southwestward through the central part of the Iron King volcanic belt into the area west and southwest of Crown King (pl. 1). This zone of dikes bisects the granodiorite stock west of Crown King exposed about $1 \frac{1}{2} \mathrm{~km}$ southward in the Crown King quadrangle $(1,176,000 \mathrm{~N}$., $368,000 \mathrm{E}$.); it has a total linear extent of about $27 \mathrm{~km}$ (Jaggar and Palache, 1905). Concordant dikes or sills of rhyolite porphyry occur widely in the vicinity of Pine Flat from the north edge of the Brady Butte area southward, nearly to Battle Flat.

The dikes are generally yellow buff to light yellowish gray; vitreous rounded bipyramidal-quartz phenocrysts, 1 to $5 \mathrm{~mm}$ in diameter are scattered through the full fine-grained to aphanitic groundmass. Chalk white argillized or sericitized plagioclase and bleached palegreenish biotite are commonly present as phenocrysts 1 to $3 \mathrm{~mm}$ in diameter. Margins are chilled, flow banded, aphanitic, and locally spherulitic. In the schistose rocks, the dikes conform closely to the adjacent $S_{2}$ foliation and range in thickness from one or more to about $30 \mathrm{~m}$. Generally the individual dikes can be traced for a thousand or more meters or even kilometers, and locally are composite and branching. Brecciated marginal zones and adjacent country rock, with or without a rhyolitic matrix, occur along the east edge of Pine Flat and in the region north and east of the quartz latite porphyry stock. A chemical analysis of a slightly altered rhyolite dike is given in table 3 .

\section{ALKALIC MAFIC AND LAMPROPHYRE DIKES}

Medium-gray to nearly black mafic dikes occur throughout the Brady Butte area, occupying northwest-trending, nearly vertical 
joints, approximately parallel to the A-C plane of the Precambrian structural coordinate system. The age of these persistent, but relatively narrow dikes is unknown. These mafic alkalic rocks were called camptonite by Jaggar and Palache (1905) on the basis of one chemical analysis. The texture and composition of the dikes are variable, and the texture and mineralogical character vary laterally and longitudinally. Two chemical analyses of widely separated dikes in the Brady Butte area are given in table 3.

Large rounded and deeply embayed phenocrysts of these minerals have been identified in individual samples: olivine, biotite, brown hornblende, augite rimmed with titanaugite, potassium feldspar, andesine rimmed with potassium feldspar, and quartz. In some specimens the phenocrysts attain maximum dimensions of more than $2 \mathrm{~cm}$. Partially fused and assimilated exotic inclusions of granite, gneiss, and pegmatite are abundant in many dikes where the nearest exposures of these included rocks are kilometers away. The fine-grained to aphanitic groundmass consists predominately of turbid interstitial potassium feldspar, needles or small prisms of reddish-brown hornblende, titanaugite, and red-brown biotite. The groundmass texture is panidiomorphic granular relatively free of megacrysts. Chilled and locally vesiculated margins are characteristic. Accessory and alteration minerals include large rounded and embayed crystals of unusual apatite (biaxial, $2 \mathrm{~V} 0^{\circ}-50^{\circ}$, generally small, positive optic sign), magnetite-ilmenite, and calcite.

The genesis of the alkalic mafic rocks and lamprophyres is poorly understood. They are not associated with any particular plutonic rock but occur widely throughout the Precambrian terrane southeast of Prescott as narrow, west- or northwest-trending, nearly vertical dikes that are conspicuous because of their variety of large resorbed megacrysts. Examination of wormy, partially assimilated granitic inclusions indicates that fusion of alkali feldspar has occurred along grain boundaries. The great abundance of these granitic fragments in some dikes suggests that partial assimilation of alkali-rich fractions has modified the composition of the original magma.

\section{CENOZOIC ROCKS}

\section{HICKEY FORMATION}

The Hickey Formation was defined by Anderson and Creasey (1958, p. 56-69) as a sequence of basaltic flows and intertonguing basaltic sediments exposed on the summit area of Mingus Mountain. In the 
Table 3.--Chemical analyses and C.I.P.W. norms of Late Cretaceous or early Tertiary rhyolitic and mafic alkaline dikes

[Chemical analyses by rapid rock method; analysts: Paul L. D. Elmore, Lowell Artis, Samuel Botts, Gillison Chloe, John Glenn, and Hezekiah Smith]

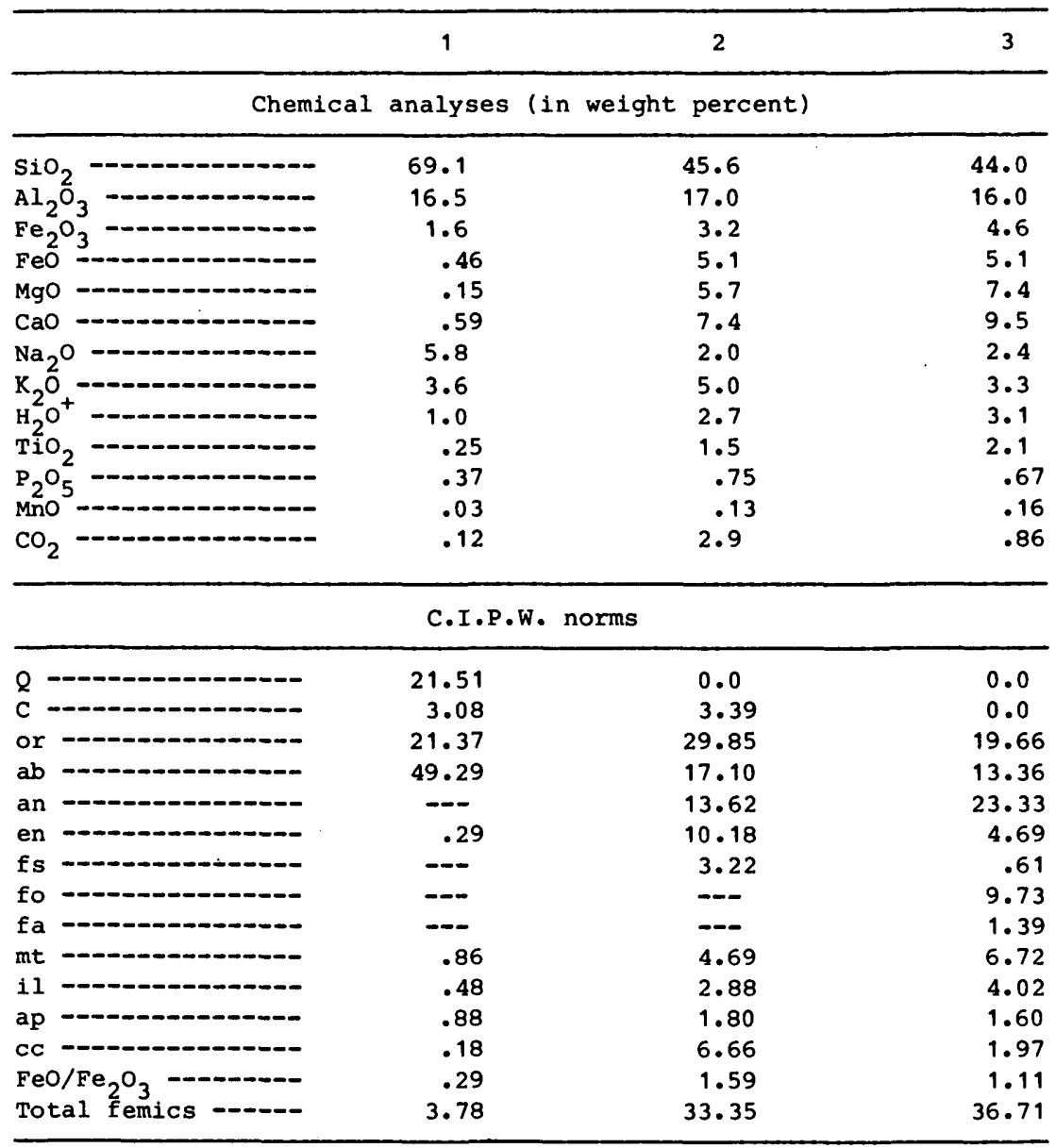

1. Flow-banded aphanitic marginal facies of rhyolitic porphyry dike $(1,217,000$ N., 394,000 E.).

2. Biotite-hornblende lamprophyre $(1,214,200 \mathrm{~N}$, 363,500 E.).

3. Biotite-hornblende lamprophyre $(1,189,000 \mathrm{~N}, 385,500 \mathrm{E}$.$) .$ 
type locality, Mingus Mountain, coarse gravel and sand are exposed, largely of nonvolcanic debris. Potassium-argon dates obtained from the volcanic rocks by Krieger, Creasey, and Marvin (1971) and McKee and Anderson (1971) indicate that the age is late Miocene and early Pliocene. Sections of Hickey Formation exposed in the map areas, the northeast corner of the $\mathrm{NE}^{1 / 4}$ Mount Union quadrangle and the northwest corner and west half of the Mayer quadrangle are southward extensions of the basaltic and sedimentary facies exposed at its type locality (Anderson and Blacet, 1972a; Anderson, 1972).

In the Brady Butte area (pl. 1), exposures of the Hickey Formation are limited to the northeast corner, where poorly consolidated nonvolcanic conglomerate with interbedded sandstone and marly siltstone are exposed below a small erosional remnant of an olivine basalt flow. Two small high-level patches of unconsolidated lag gravel more than $120 \mathrm{~m}$ above the present drainage $3 \mathrm{~km}$ southwest of the main exposures of the Hickey Formation probably represent remnants of Pliocene(?) stream gravel. Well-rounded clasts, ranging upward in size to boulders $0.9 \mathrm{~m}$ in diameter, are predominantly granitic rocks. A few distinctive boulders of coarsely porphyritic granodiorite indicate a source area to the southwest in the vicinity of Tuscumbia Mountain. Perhaps a Pliocene(?) stream channel, with its headwaters in the southwest corner of the area,.drained northeastward down an ancestral Bear Creek into an eastward-flowing valley in the vicinity of the exposed Hickey gravel and capping of Hickey basalt. Eastward in the Cordes area, extensive basaltic flows are exposed overlying Hickey gravel and sand (Anderson, 1972, pl. 1).

\section{REDDISH GRAVEL}

Reddish gravel deposits conforming to topography but elevated a meter or so above the present-day streams and gullies cover large areas of the northeastern corner of the Brady Butte area and Battle Flat. Typically mantled with soil, they were sites for prehistoric Indian occupation and cultivation. These alluvial gravels locally grade into low-stream terraces and modern stream gravels. A few small gold placers have been worked in small recent stream bars or terraces, mostly along the lower course of Turkey Creek and in the Quaternary gravel deposits on Pine Flat.

\section{ORE DEPOSITS}

Mining activity in the northern Bradshaw Mountains began in 1863 with the discovery of gold placers south and east of Prescott. Lode mining began about 1875 in the general region. The Peck mining district in the Brady Butte area occupies an area of about $5 \mathrm{~km}^{2}$ in the 
drainage areas of Peck Canyon and Bear Creek. The three principal mines, Peck, Swastika, and De Soto, occur in the Iron King Volcanics.

The Peck silver mine was discovered by E. G. Peck in 1875 . The surface outcrop was rich in silver and claims were staked. Ten tons of surface ore was sold in Prescott for $\$ 1,300$ per ton. A roaster and 10stamp mill were installed and worked successfully (Dunning and Peplow, 1959, p. 82). Three veins, in places several feet wide, follow the strike and dip of the schistose rocks, $\mathrm{N} .25^{\circ} \mathrm{E} .75^{\circ} \mathrm{W}$. The ore was darkbrown quartz and limonite. Green bromyrite was the principal ore mineral, but rich native silver ore was reported. About $\$ 1$ to $\$ 1 / 2$ million in silver is the reported production between 1875 and 1885 (Lindgren, 1926, p. 161).

The Swastika mine, about three-fourths kilometer south of the Peck mine, consisted of the Black Warrior and Silver Prince veins. Raymond's report of 1877 stated that the cost of packing the ore to Prescott was $\$ 50$ a ton. The U.S. Mint report for 1883 mentions both veins, stating that the Black Warrior was $1 / 2$ to $1 \mathrm{~m}$ wide, that silver valued at $\$ 40,000$ had been extracted to that time, and that 8 tons per day was milled in a four-stamp mill for a yield of $35.4 \mathrm{gm}$ of silver per ton. In 1885 , the mine was thought to have been worked out, but it was reopened by $\mathrm{F}$. W. Woods in 1910 . By 1915 , the mine had produced an additional $1,866 \times 10^{3} \mathrm{gm}(600,000 \mathrm{oz})$ of silver, bringing the total production to about $31 \times 10^{6} \mathrm{gm}$ (1 million oz) (Lindgren, 1926, p. 162). In 1934-35, the Swastika was reopened and produced $150,000 \mathrm{oz}$. A mill was built by the Sterling Gold Mining Co. in 1936, but the ore proved difficult to treat by milling. Intermittent mining from 1936 to 1952 produced $4.7 \times 10^{6} \mathrm{gm}(150,000 \mathrm{oz})$. The total ore from the Swastika mine is reported to have been valued at about $\$ 1$ million (Dunning and Peplow, 1959, p. 382).

The De Soto copper mine is about $3 \mathrm{~km}$ northeast of the Peck mine on the summit of a ridge separating Peck Canyon from Crazy Basin. The main tunnel is about $180 \mathrm{~m}$ below the outcrop. The ore bodies, pyrite and chalcopyrite in chloritic schist, occur in the lower part of the Iron King Volcanics as overlapping lenses constituting an ore zone $105 \mathrm{~m}$ in total length. The grade of ore mined was 2.25 to 3.75 percent copper, 31 gm $(1 \mathrm{oz})$ silver, and $0.6 \mathrm{gm}(0.02 \mathrm{oz})$ gold per ton.

There is no reliable information available concerning the seven mines located in the western half of the Brady Butte area.

\section{REFERENCES CITED}

Anderson, C. A., 1967, Precambrian wrench fault in central Arizona, in Geological Survey research 1967: U.S. Geological Survey Professional Paper 575-C, p. C60-C65. 1972, Precambrian rocks in the Cordes area, Yavapai County, Arizona: U.S. Geological Survey Bulletin 1345, p. 1-36. 
Anderson, C. A., and Blacet, P. M., 1972a, Precambrian geology of the northern Bradshaw Mountains, Yavapai County, Arizona: U.S. Geological Survey Bulletin 1336, 82 p. $-1972 b$, Geologic map of the Mount Union quadrangle, Yavapai County, Arizona:

U.S. Geological Survey Geologic Quadrangle Map GQ-997, scale 1:62,500.

1972c, Geologic map of the Mayer quadrangle, Yavapai County, Arizona: U.S. Geological Survey Geologic Quadrangle Map GQ-996, scale 1:62,500.

Anderson, C. A., Blacet, P. M., Silver, L. T., and Stern, T. W., 1971, Revision of Precambrian stratigraphy in the Prescott-Jerome area, Yavapai County, Arizona: U.S. Geological Survey Bulletin 1324-C, 16 p.

Anderson, C.A., and Creasey, S. C., 1958, Geology and ore deposite of the Jerome area, Yavapai County, Arizona: U.S. Geological Survey Professional Paper 308, 185 p. 1967, Geologic map of the Mingus Mountain quadrangle, Yavapai County, Arizona: U.S. Geological Survey Geologic Quadrangle Map GQ-715, scale 1:62,500.

Bateman, P. C., Clark, L. D., Huber, N. K., Moore, J. G., and Rinehart, C. D., 1963, The Sierra Nevada batholith-A synthesis of recent work across the central part: U.S. Geological Survey Professional Paper 414-D, p. D1-D46.

Blacet, P. M., 1966, Unconformity between gneissic granodiorite and overlying Yavapai Series (older Precambrian), central Arizona, in Geological Survey research 1966: U.S. Geological Survey Professional Paper 550-B, p. B1-B5.

Clarke, F. W., 1924, Data of geochemistry, 5th ed.: U.S. Geological Survey Bulletin 770, $841 \mathrm{p}$.

Dale, V. B., 1961, Tungsten deposits of Gila, Yavapai, and Mohave Counties, Arizona: U.S. Bureau of Mines Information Circular 8078, $104 \mathrm{p}$.

Deer, W. A., Howie, R. A., and Zussman, J., 1963, Framework silicates, v. 4, of Rockforming minerals: New York, John Wiley, $435 \mathrm{p}$.

DeWitt, E., 1976, Precambrian geology and ore deposits of the Mayer-Crown King area, Yavapai County, Arizona: Tucson, Arizona University, M.S. thesis, 150 p.

Dunning, C. H., and Peplow, E. H., 1959, Rock to riches: Phoenix Ariz., Southwest, 406 p.

Harrer, C. M., 1964, Reconnaissance of iron resources in Arizona: U.S. Bureau of Mines Information Circular 8236, $204 \mathrm{p}$.

Jaggar, T. A., and Palache, Charles, 1905, Description of Bradshaw Mountains quadrangle [Arizona]: U.S. Geological Survey Geologic Atlas, Folio 126, 11 p.

James, H. L., 1955, zones of regional metamorphism in the Precambrian of northern Michigan: Geological Society of America Bulletin, v. 66, p. 1455-1487.

James, H. L., Clark, L. D., Lamey, C. A., and Pettijohn, F. J., 1961, Geology of central Dickinson County, Michigan: U.S. Geological Survey Professional Paper 310, 176 p.

Krieger, M. H., 1965, Geology of the Prescott and Paulden quadrangles, Arizona: U.S. Geological Survey Professional Paper 467, $127 \mathrm{p}$.

Krieger, M. H., Creasey, S. C., and Marvin, Richard, 1971, Ages of some Tertiary andesitic and latitic volcanic rocks in the Prescott-Jerome area, north-central Arizona, in Geological Survey research 1971: U.S. Geological Survey Professional Paper 750-B, p. B157-B160.

Laniz, R. V., Stevens, R. E., and Norman, M. B., 1964, Staining of plagioclase feldspar and other minerals with F. D. and C. red No. 2: U.S. Geological Survey Professional Paper 501-B, p. B152-B153.

Lehner, R. E., 1958, Geology of the Clarkdale quadrangle, Arizona: U.S. Geological Survey Bulletin 1021-N, p. 511-592.

Lindgren, Waldemar, 1926, Ore deposits of the Jerome and Bradshaw Mountains quadrangles, Arizona: U.S. Geological Survey Bulletin 782, 192 p.

McKee, E. H., and Anderson, C. A., 1971, Age and chemistry of Tertiary volcanic rocks in north-central Arizona and relation of the rocks to the Colorado Plateau: Geological Society of America Bulletin, v. 82, p. 2767-2782.

Turner, F. J., and Verhoogen, J., 1960, Igneous and metamorphic petrology: New York, McGraw-Hill, 694 p. 
Winchell, A. N., and Winchell, H., 1951, Elements of optical mineralogy: New York, John Wiley, 551 p. 